\author{
TOMASZ SZWACIŃSKI \\ https://orcid.org/0000-0002-5209-3515 \\ Warszawa
}

\title{
STARANIA CZARTORYSKICH O WCIĄGNIĘCIE ROSJI W SPRAWY POLSKIE W 1754 ROKU (SPRAWA RZEKOMEJ GWARANCJI)
}

\begin{abstract}
Abstrakt: W grudniu 1754 r. Michał i August Czartoryscy wysłali do kanclerza rosyjskiego Aleksego Bestużewa-Riumina dwa listy. Prosili w nich o wsparcie Petersburga, bowiem uważali, że w Rzeczypospolitej doszło do złamania podstawowych praw. Za podstawę prawną rosyjskiej ingerencji uznali rzekomą gwarancję polskiego ustroju.
\end{abstract}

Słowa kluczowe: Rosja, Rzeczpospolita, Warszawa, Petersburg, dyplomacja, gwarancja, Michał Fryderyk Czartoryski, August Aleksander Czartoryski.
Abstract: In December 1754, Michał and August Czartoryski sent two letters to the Russian Chancellor Aleksei Bestuzhev-Riumin. They asked for the support of St Petersburg since they believed that fundamental rights had been violated in the Commonwealth. They considered the Russian Empire's alleged guarantee of the Polish political system to be the legal basis of Russian intervention.

Keywords: Russia, Polish-Lithuanian Commonwealth, Warsaw, St Petersburg, diplomacy, guarantee, Michał Fryderyk Czartoryski, August Aleksander Czartoryski.

Ponad sto lat temu Władysław Konopczyński, opisując wydarzenia związane z zerwaniem sejmu $1754 \mathrm{r}$. i działaniami świeżo przeszłych do opozycji antydworskiej przywódców stronnictwa Familii, kanclerza litewskiego Michała Fryderyka i wojewody ruskiego Augusta Aleksandra Czartoryskich, napisał: „,nie wiemy na pewno, czy sami Czartoryscy powołali się wtedy na jedyną domniemaną podstawę [ingerencji Rosji w sprawy polskie] - traktat warszawski 3 listopada 1716 r. [- -]. Jeżeli tak postąpili, to popełnili - aczkolwiek nie pierwsi - błąd ogromny, 
największy błąd w swojem życiu"1. Kwerenda w źródłach przechowywanych w moskiewskim Archiwum Polityki Zagranicznej Imperium Rosyjskiego (AVPRI) pozwala nam dziś bez żadnych wątpliwości odpowiedzieć na pytanie postawione przez wybitnego historyka.

Sytuacja zaistniała w Rzeczypospolitej po sejmie $1754 \mathrm{r}$. w niewielkim zakresie była dotąd przedmiotem badań. Po Konopczyńskim jedynie w późniejszym o ponad sto lat tekście podjęto opartą o nowe źródła refleksję nad staraniami Czartoryskich o wciągniecie Rosji w polski kryzys $1754 \mathrm{r}^{2} \mathrm{O}$ wydarzeniach z tego czasu wspomniała także w szerokim kontekście Zofia Zielińska3 . Napomknął wprawdzie o nich David Bayne Horn, jednak jego studium pozostawia wiele do życzenia tak w zakresie ścisłości przedstawienia zdarzeń, jak i interpretacji ${ }^{4}$.

Obszerniejszą literaturę przedmiotu ma natomiast problematyka samej mediacji oraz rzekomej rosyjskiej gwarancji traktatu warszawskiego i konstytucji Sejmu Niemego 1717 r., oraz odwoływania się do nich w latach 1715-1734. Stąd w pierwszej części tekstu zrekapitulowano dotychczasowe badania (przede wszystkim Józefa Gierowskiego, Zofii Zielińskiej i Jacka Burdowicza-Nowickiego ${ }^{5}$ ) dotyczące tego tematu. Następnie opisane zostały przypadki przywoływania rosyjskiej mediacji lub rzekomej gwarancji, zasygnalizowane w moim wcześniejszym tekście poświęconym relacjom dyplomatów rosyjskiego i brytyjskiego na temat zerwania sejmu 1754 r. ${ }^{6} \mathrm{~W}$ głównej części wywodu, w oparciu o datowane od 11 listopada do końca grudnia $1754 \mathrm{r}$. raporty ministra rosyjskiego przy dworze króla polskiego Augusta III, Heinricha Grossa, i ambasadora brytyjskiego, Charlesa Hanbury'ego Williamsa, szczegółowo opisane

${ }^{1}$ W. Konopczyński, Polska $w$ dobie wojny siedmioletniej, cz. 1: 1755-1758, Kraków-Warszawa 1909 s. $14-15$.

2 T. Szwaciński, Finał sejmu 1754 r. w relacjach rosyjskich i brytyjskich, „Biblioteka Epoki Nowożytnej" 4, 2016, 1, s. 163-193.

${ }^{3}$ Z. Zielińska, Echa dokonań Sejmu Niemego w czasach Augusta III i Stanisława Augusta (rekonesans), w: Sejm Niemy. Między mitem a reforma państwa, red. M. Zwierzykowski, Warszawa 2019. s. 286-327.

${ }^{4}$ D. Horn, Sir Charles Hanbury Williams and European Diplomacy (1747-1758), LondonBombay-Sydney 1930, s. 170. Gdyby zestawić pełny katalog błędów, przeinaczeń i nieuzasadnionych stereotypów, których dopuszcza się Horn, opisując sprawy polskie i rosyjskie, wyszłaby sporych rozmiarów publikacja.

${ }^{5}$ J. Gierowski, Wokół mediacji w Traktacie Warszawskim 1716 roku, w: idem, Na szlakach Rzeczypospolitej w nowożytnej Europie, red. A.K. Link-Lenczowski, Kraków 2008, s. 513-522 (pierwodruk: 1969); Z. Zielińska, Echa dokonań, s. 286-327; J. Burdowicz-Nowicki, Polityka Piotra I w zwiazku ze sprawą toruńska 1724 r., w: W cieniu wojen i rozbiorów. Studia z dziejów Rzeczypospolitej XVIII i początków XIX wieku, red. U. Kosińska, D. Dukwicz, A. Danilczyk, Warszawa 2014, s. 77-103.

${ }^{6}$ T. Szwaciński, Finał sejmu 1754 r., s. 163-193. 
zostały wypadki bezpośrednio poprzedzające tytułowe wydarzenie. Następnie przedstawiono, rozstrzygający przywołaną na wstępie wątpliwość Konopczyńskiego, corpus delicti, to jest listy Michała Fryderyka i Augusta Aleksandra Czartoryskich z 19 i 20 grudnia 1754 r. wysłane do Petersburga ${ }^{7}$. Całość zamykają obszerne fragmenty instrukcji dla nowego dyplomaty rosyjskiego w Warszawie, Michaiła Nikitycza Wołkonskiego (Mihail Volkonskij), z 1757 r., które - wydaje się - nie pozostawały bez związku z opisywanymi tu działaniami przywódców Familii.

Pytanie, w jaki sposób rozumiano termin „gwarancja” w prawie międzynarodowym Europy nowożytnej, czym ona była w teorii i kiedy działała w praktyce, pozostaje otwarte i czeka na swojego badacza ${ }^{8}$. Na potrzeby niniejszego tekstu, w oparciu o wykorzystane źródła i literaturę, przyjmuję, że gwarancja była prawem sankcjonowania zmian ustrojowych w Polsce i podstawą legitymizującą interwencję (dyplomatyczną lub zbrojną) w przypadku nieuznanych przez gwaranta zmian ustroju lub na wypadek wybuchu wewnętrznego konfliktu. Przy czym to Rosja zastrzegała sobie orzecznictwo, kiedy zaistniały podstawy do wypełnienia rzekomych postanowień gwarancyjnych.

Wydarzenia, które miały miejsce bezpośrednio po rozdwojonej elekcji w 1697 r., doprowadziły do katastrofalnego spadku międzynarodowego znaczenia Rzeczypospolitej, a w dalszej perspektywie do faktycznej utraty możliwości samostanowienia szlacheckiej republiki. Podstawowym kierunkiem, w którym odbywał się transfer strategicznych decyzji w sprawach polskich, był wschód. Jak skonstatował Jacek Burdowicz-Nowicki: „Elekcja 1697 r., mimo rozdwojenia, stanowiła jeszcze suwerenną decyzję narodu szlacheckiego - Moskwa nie miała możliwości realnego jej pogwałcenia. Po abdykacji Wettina w Altranstädt Piotr [car Piotr I - T.S.] uznał się za dysponenta polskiej korony, planując obsadzić tron polski wedle własnego zdania"9. Bardzo ważnym etapem budowy rosyjskiej dominacji były wydarzenia z lat 1716-1717, kiedy to doszło do porozumienia między królem Augustem II a stanami Rzeczypospolitej

${ }^{7}$ Relacje H. Grossa z Warszawy i Drezna od 17 XI do 23 XII 1754 wraz z załącznikami, Arhiv Vnešnej Politiki Rossijskoj Imperii (dalej: AVPRI), f. 79/1, d. 1754/5, k. 293477. Relacje Williamsa z Warszawy, od 11 XI do 25 XII 1754, The National Archives State Papers (dalej: TNA SP) 88/76, k. 221-314. Listy M.F. i A.A. Czartoryskich z Warszawy do A.P. Bestużewa-Riumina z rosyjskimi tłumaczeniami, 19 i 20 XII 1754, AVPRI, f. 79/1, d. $1754 / 2$, k. 32-40v.

${ }^{8}$ Uwagę na to zwrócił mi Jacek Burdowicz-Nowicki, za co pragnę złożyć dowody wdzięczności, podobnie jak za inne cenne rady i sugestie udzielane mi przy pisaniu niniejszego tekstu.

9 J. Burdowicz-Nowicki, Piotr I, August II i Rzeczpospolita 1697-1706, Kraków 2010, s. 11 i passim. 
przy rosyjskiej mediacji i po wkroczeniu carskich wojsk do kraju ${ }^{10}$. Mimo prób Augusta II wyzwolenia się spod rosyjskiej kurateli, podejmowanych w latach następnych, oraz chwilowego osłabnięcia wschodniego imperium, w latach 1725-1730 nie doszło do zmian w układzie geopolitycznym Europy Środkowo-Wschodniej ${ }^{11}$. Niebudzącym wątpliwości dowodem na to są dzieje bezkrólewia, elekcji i wojny z lat 1733-1736, bowiem sprawa obsady polskiego tronu w najmniejszym stopniu zależała od suwerena ${ }^{12}$. W czasach panowania Augusta III dotyczyło to także innych fundamentalnych spraw polskiej państwowości ${ }^{13}$.

Odzieranie Polski z samostanowienia przez Rosję, czynione prostą drogą faktów dokonanych, było naturalną konsekwencją rosnącej przewagi militarnej ${ }^{14}$, wykorzystywania przez sąsiadów patologii polskiego ustroju $\mathrm{u}^{15}$ oraz istnienia wśród elity Rzeczypospolitej czeredy rosyjskich jurgieltników ${ }^{16}$. Jednak petersburscy „legaliści” nie byli wolni od refleksji, że korzystne byłoby dla Rosji stworzenie podstaw prawnych ingerowania w wewnętrzne sprawy Polski. Sugestie takie padały ze strony samych Polaków, nie bez powodu podejrzewających własnego króla o nieczystą grę wobec Rzeczypospolitej. Najbardziej dogodny moment sformalizowania rosyjskiej dominacji pojawił się po zawiązaniu skierowanej przeciwko rządom Augusta II konfederacji tarnogrodzkiej. Tym bardziej że wydarzenia te, wedle badań Wojciecha Kriegseisena, były w pewnym stopniu przez Rosję sprowokowane. W listopadzie 1715 r. Piotr I zwrócił się do stanów Rzeczypospolitej, oferując mediację rosyjskiego dyplomaty Grigorija Dołgorukowa (Grigorij Dolgorukov) w sporze konfederatów z królem Augustem II. W nieco wcześniejszych rosyjskich przekazach pojawiła się sugestia, aby car, zostając gwarantem porozumienia (w tym przypadku

10 Problematykę lat 1716-1717 podejmują zbiory: Sejm Niemy. Między mitem oraz Studia nad konfederacja tarnogrodzka i Sejmem Niemym, red. T. Ciesielski, Warszawa 2020. W obu przypadkach obszerna i wyczerpująca bibliografia literatury przedmiotu.

11 Inter alia: U. Kosińska, Sejm 1719-1720 a sprawa ratyfikacji traktatu wiedeńskiego, Warszawa 2003, passim; eadem, August II w poszukiwaniu sojusznika. Między aliansem wiedeńskim i hanowerskim (1725-1730), Warszawa 2012, passim.

${ }^{12}$ Inter alia: J. Dygdała, Gra pozorów. Zabiegi dyplomacji cesarskiej o rosyjska interwencje zbrojna w Rzeczypospolitej w 1733 r., w: W cieniu wojen i rozbiorów, s. 137-160.

13 Inter alia: Z. Zielińska, Walka „Familii” o reformę Rzeczypospolitej 1743-1752, Warszawa 1983, passim; eadem, Rosja wobec polskich prób reform w latach 1738-1744, w: eadem, Studia z dziejów stosunków polsko-rosyjskich w XVIII w., Warszawa 2001, s. 9-59.

${ }^{14}$ Inter alia: T. Ciesielski, Armia koronna w czasach Augusta III, Warszawa 2009, passim.

${ }^{15}$ Inter alia: U. Kosińska, Liberum veto jako narzędzie niszczenia sejmów przez państwa ościenne w czasach Augusta II, „Biblioteka Epoki Nowożytnej” 4, 2016, 1, s. 127-161.

${ }^{16}$ Inter alia: U. Kosińska, U źródeł zjawiska odwoływania się do potencji ościennych w polskich sporach wewnętrznych - casus roku 1730, SDRE 54, 2019, 1, s. 5-26. 
hetmana wielkiego litewskiego Ludwika Pocieja z dworem), uzyskał prawo wprowadzania wojska do Rzeczypospolitej w celu rozstrzygania konfliktów między monarchą a poddanymi. Obie strony konfliktu przystały na ofertę mediacji w lutym $1716 \mathrm{r}$. Szczegółowe zasady pośrednictwa zostały ustalone dwa miesiące później w Gdańsku. Wedle nich, jeżeli któraś ze stron konfliktu zaczęłaby uniemożliwiać porozumienie, Dołgorukow miał prawo wezwać do Rzeczypospolitej korpus wojska rosyjskiego w celu wywarcia odpowiedniej presji. Początkowo sami konfederaci nalegali na rosyjską gwarancję. Jej wyraźne pożądanie przez Piotra I wyrażała także instrukcja dla Dołgorukowa. Mimo to, wobec sprzeciwu Augusta II, carska gwarancja nie znalazła się w gdańskich „kondycjach”. Próby konfederatów, aby zaangażować w polski konflikt Turcję lub cesarza, co mogło złagodzić rosyjski uścisk, zakończyły się niepowodzeniem, choć pod pewnym względem wzmocniły ich pozycję negocjacyjną. W sierpniu 1716 r., po zerwaniu przez konfederatów rozmów z przedstawicielami króla w Lublinie, Dołgorukow wezwał do Rzeczypospolitej rosyjski korpus. Negocjacje wznowiono we wrześniu w Warszawie. Teraz już obie strony polskiego sporu twardo przeciwstawiły się rosyjskiej gwarancji, przez co carski dyplomata, mimo wytężonych starań, nie przeforsował wprowadzenia jej do tekstu podpisanego 3 listopada 1716 r., przy jego własnej mediacji, porozumienia. Jak podkreślił Józef Gierowski: Rosjanin „traktatu warszawskiego ani nie układał, ani nie dyktował”, a zakres jego oddziaływania na sprawy polskie pozostawał ograniczony (m.in. ustąpić musiał w sprawie przysięgi hetmańskiej i „opisania” tego urzędu w traktacie warszawskim). Dołgorukow zapewniał jednak cara, w depeszy z 9/20 listopada 1716 r., że „chociaż, Wasza Carska Mość, ja ostrożnie na rzecz gwarancji jak to tylko możliwe pracowałem, obie strony nie życzą jej sobie, wszelako bez niej nie obejdzie się, gdy jedna strona drugiej nie wierzy, więc sądzę, że może ona w przyszłości działać w sposób naturalny"17.

17 Cyt. za J. Gierowski, Wokół mediacji, s. 513-522. Nieco inne spojrzenie na problematykę mediacji Dołgorukowa w niniejszym tekście w najmniejszym stopniu nie może być podstawą kwestionowania zasadniczych zasług Józefa Gierowskiego w badaniach tego zagadnienia. Z uwagi na wykorzystanie raportów Dołgorukowa muszą być one punktem wyjścia dla dalszych poszukiwań w Rosyjskim Państwowym Archiwum Akt Dawnych (RGADA). Dlatego zrezygnowanie z ich podsumowania nie jest trafnym rozwiązaniem w przypadku historyka (K. Kościelniak, Obraz mediacji rosyjskiej w listach Stanisława Ledóchowskiego adresowanych do Grzegorza Dołgorukiego z lipca i sierpnia 1716 roku znajdujących się w RGADA w Moskwie, w: Studia nad konfederacją, s. 131-142), który postanowił podjąć ten temat. Na temat rosyjskiej mediacji w konflikcie między królem a konfederatami, patrz też inter alia: J. Gierowski, „Opisanie” urzędów centralnych przez konfederatów tarnogrodzkich, w: idem, Na szlakach, s. 533-549 (pierwodruk: 1965); idem, Traktat przyjaźni Polski z Francja w 1714 r., Warszawa 1965, s. 207-240; W. Kriegseisen, 
Mimo porażki Dołgorukowa, którą - wydaje się - przesadnie akcentował Gierowski, został stworzony niezwykle niebezpieczny precedens, którym był sam fakt sformalizowanej rosyjskiej mediacji w wewnętrznym polskim konflikcie. Ponadto przegrana z pozoru sprawa gwarancji zaczepiła się w świadomości rosyjskich twórców polityki zagranicznej, pojawiła się w dokumentacji i nie została zapomniana.

Postanowienia lat 1716-1717 mają szczególnie znaczenie dla podjętego tematu, bowiem akta sejmikowe i inne źródła dowodzą, że przyjęte w traktacie warszawskim i w konstytucjach Sejmu Niemego rozwiązania prawne przez długie dziesięciolecia były traktowane w Rzeczypospolitej jako prawo zasadnicze, stanowiące często punkt odniesienia. Wydarzenia i decyzje $z$ tego okresu nie miały w świadomości społeczeństwa negatywnych konotacji i odwoływano się do przyjętych wówczas rozwiązań w bardzo wielu obszarach życia publicznego. W dotychczasowych badaniach wskazano, że najczęściej występującym postulatem było zachowanie zasad współżycia między wojskiem a społeczeństwem, wedle przyjętej w 1717 r. konstytucji Disciplina militaris. Także projekty powiększenia armii odwoływały się do ustawodawstwa Sejmu Niemego. Dyskutowano zniesienie ulgi podatkowej województw południowo-wschodnich (koekwacja) oraz uskarżano się na pogłówne w Koronie i podymne na Litwie. Podnoszono w różnych kontekstach sprawę przyjętego w 1717 r. ograniczenia władzy hetmańskiej, w tym zakaz korespondencji hetmanów z zagranicą. Natomiast wymóg, aby urzędy hetmańskie były obsadzane dopiero po ukonstytuowaniu się sejmu, był krytykowany i został zniesiony w 1736 r. Powszechnie szlachta dopominała się respektowania usankcjonowanego przez Sejm Niemy pozbawienia innowierców praw politycznych. W uchwałach sejmikowych powtarzały się żądania wyprowadzenia z Rzeczypospolitej wojsk cudzoziemskich, co gwarantowała konstytucja sejmu 1717 r. Przypominano ustaloną wówczas maksymalną liczbę wojsk saskich (1200), mogących przebywać w kraju. Pojawiały się także dezyderaty nieprzekraczania kompetencji rad senatu ${ }^{18}$.

Тарногродская конфедерациия (1715-1717 г2.): проявление внутреннего кризиса шляхетской Речи Посполитой или результат конфликта в отношениях России с Саксонией?, w: Россия, Польша Германия в европейской политике. Исторический опыт взаимодействия и императивы сотрудничества, red. Б.В. Носов, Москва 2012, s. 101-115; M. Šapoka, Konfederacja Wielkiego Księstwa Litewskiego 1715-1716 roku i jej wpływ na negocjacje przed Sejmem Niemym, w: Sejm Niemy. Między mitem, s. 22-36; idem, Warfare, Loyalty, and Rebellion. The Grand Duchy of Lithuania and the Great Northern War, 1709-1717, London 2018; K. Kościelniak, Trudnych rozmów początki. Korespondencja Stanisława Ledóchowskiego z Grigorijem Dotgorukim podczas negocjacji w Lublinie w 1716 roku, w: Sejm Niemy. Między mitem, s. 89-112.

18 Z. Zielińska, Echa dokonań, s. 286-317. 
Zaprezentowany powyżej niekompletny katalog spraw państwowych, przy okazji których w dyskursie publicznym odwoływano się do ustawodawstwa Sejmu Niemego, pomija kwestię rzekomej rosyjskiej gwarancji obejmującej postanowienia owego zgromadzenia. W uchwałach sejmikowych tematu tego nie podejmowano.

Tymczasem sprawa rzekomej rosyjskiej gwarancji pojawiła się już w pierwszych latach po Sejmie Niemym w kontekście tzw. sprawy dysydenckiej. Traktat warszawski 1716 r. zakładał ograniczenie praw polskich ewangelików. Było to możliwe m.in. dzięki obojętności mediatora (Rosji) wobec tego zagadnienia. Akcja duchowieństwa katolickiego wymierzona w innowierców, która nastąpiła rychło po podpisaniu traktatu, spowodowała reakcję poszkodowanych w postaci odwołania się do cara Piotra I jako mediatora tegoż traktatu. Daniel Ernest Jabłoński, przywódca polskich protestantów, namówił także króla pruskiego Fryderyka Wilhelma I, aby ten starał się skłonić cara do wystosowania gramoty do króla polskiego Augusta II w obronie protestantów. Car miał powołać się - wedle nadziei Jabłońskiego - na status mediatora oraz gwaranta traktatu warszawskiego i skłonić polskiego monarchę do korzystnej dla ewangelików interpretacji postanowień z 1716 r. Piotr I nie zamierzał być jednak narzędziem realizacji cudzych interesów i zwlekał z wypełnieniem pruskich postulatów. Nie chcąc jednak zrazić ważnego sojusznika, jakim był Fryderyk Wilhelm I, car zastosował grę pozorów. Dopiero gdy w czerwcu 1724 r. dotarły do Moskwy relacje rosyjskiego dyplomaty w Warszawie, Siergieja Dołgorukowa (Sergej Dolgorukov) o groźbie dojścia sejmu i aukcji wojska, Piotr I zdecydował się na działania, o które prosili go Prusacy. Służyło to zacieśnieniu współpracy z Berlinem w akcji wymierzonej przeciwko wzmocnieniu się Rzeczypospolitej. 6/17 sierpnia 1724 r. została wyekspediowana z Petersburga gramota, w której władca Rosji wstawiał się za protestantami i prawosławnymi, powołując się na status gwaranta i mediatora traktatu warszawskiego i protestując przeciwko niekorzystnej dla niekatolików interpretacji traktatu. Mimo to jako główny pretekst prawny interwencji przedstawiony został traktat Grzymułtowskiego z 1686 r. Ze względów taktycznych rosyjscy dyplomaci gramotę przedstawili dopiero 23 listopada 1724 r. na prywatnej audiencji u króla polskiego. $\mathrm{W}$ tym samym roku doszło do spowodowanego konfliktami międzywyznaniowymi tumultu toruńskiego, który został wykorzystany politycznie przez państwa protestanckie - Prusy i Wielką Brytanię. Jednak koincydencja rosyjskich działań z tym wydarzeniem była przypadkiem ${ }^{19}$.

19 J. Burdowicz-Nowicki, Polityka Piotra I, s. 77-103; patrz także: W. Kriegseisen, Postanowienia Sejmu Niemego $w$ kwestiach wyznaniowych i ich konsekwencje, czyli w sprawie 
U schyłku panowania Augusta II zagadnienie rzekomej gwarancji podjął Stanisław Konarski w drukowanej broszurze Rozmowa pewnego Ziemianina ze swoim sasiadem. O teraźnieyszych okolicznościach. Broszura powstała, aby uzasadnić ewentualne oddanie buławy wielkiej koronnej jednemu z liderów Familii, Stanisławowi Poniatowskiemu, musiała być zatem przez przywódców stronnictwa znana i akceptowana. Tekst został skonstruowany jako dialog Ziemianina, z którym utożsamiał się autor, z Sąsiadem, wyrażającym odmienne poglądy ${ }^{20}$. Sąsiad przekonywał „Tertio: Bo gwarancyja moskiewska na tym traktacie powinna być w wielkiej aprehensyi". Ziemianin odpowiadał m.in.:

Więc na tę pogróżkę, że mediacyja moskiewska nie dopuści in tanta necessitate dyspensować prawa traktatowego, należącego mere do dobrego ab intra Rzeczypospolitej rządu, co W. Panu mam odpowiedzieć? Vox faucibus haeret. Non metu, żeby się dwór moskiewski miał mieszać in dispositiones praw Rzeczypospolitej, mądra tam teraz, choć biała, głowa. [--] Mądre ministeria, pares castrisque togaeque, wiedzą dobrze, co do mediacyi należy, wiedzą, że Respublica jest independens iurium suorum domina, żeby to było barzo w sąsiedzką wdawać się ekonomią, contra ius gentium w partykularne państwa naszego tak ciekawie wdawać się prawa. A cóż to do moskiewskiej mediacyi? Ale na to tylko eripit verba dolor, jak w życzliwego ojczyźnie syna sercu skoncypowane, jak ustami wyrażone być może tam ferale medium dla utrzymania swojej pretensyi. [--] Nie trzeba by nam inszego przykładu szukać zapamiętałego przywiązania do swoich prywat, gdyby się tak stać miało. W. Pan, kochający ojczyznę i poczciwość, trzymam, że gieneralnie de proditoribus patriae tenże masz, co i każdy, sentyment: [--] Gdyby do tego przyszło, przyszłaby ad praxin i owa, jeśli się nie mylę, Seneki, maksima: tantum virium fumendum est, quantum eis accessit, quae adversus te praeparantur, armaque in armatos sumere iura sinunt. Więcej o tym nie mówmy ${ }^{21}$.

W tekście, w którym spoza makaronicznego stylu wyziera już geniusz reformatora polskiego myślenia politycznego, explicite zostały wyrażone podstawowe kwestie: 1) Piotr I był mediatorem, a nie gwarantem

genezy „sprawy dysydenckiej”, w: Sejm Niemy. Między mitem, s. 177-188; U. Kosińska, August II w poszukiwaniu sojusznika. Między aliansem wiedeńskim i hanowerskim (1725-1730), Warszawa 2012, s. 116-123.

${ }^{20}$ W. Konopczyński, Stanisław Konarski, Warszawa 1926, s. 44-48; Z. Zielińska, Echa dokonań, s. 317-318.

${ }^{21}$ [S. Konarski], Rozmowa Ziemianina ze swoim sąsiadem. O teraźnieyszych okolicznościach, [Warszawa 1733], s. 45, 48-50. Inny fragment tej części Rozmowy zacytowany był już w: W. Konopczyński, Polska $w$ dobie, s. 317. Konopczyński przytoczył tłumaczenie Seneki: „wydobyć z siebie tyle sił, ile ich przybyło na poparcie usiłowań przeciwnych, prawo pozwala zbroić się przeciw zbrojnym", W. Konopczyński, Stanisław Konarski, s. 47. 
traktatu warszawskiego; 2) z faktu mediacji nie wynikają żadne skutki prawne; 3) wzywanie pomocy rosyjskiej w oparciu o prawo z $1717 \mathrm{r}$. jest zdradą stanu, wobec której należy podjąć adekwatne środki. Rozmowa Konarskiego wyszła spod prasy tuż przed śmiercią Augusta II (1 II 1733). Bezkrólewie i walka o tron polski sprawiły, że spór o rzekomą gwarancję wybuchł z nową siłą. Publicystyka inspirowana przez ambasady dworów cesarskich dowodziła, że Rosja miała prawo działać w obronie polskiej wolności w oparciu o traktat warszawski, a Austria uzyskała takie prawo na mocy traktatu polsko-austriackiego 1732 r. Argumentu rosyjskiej gwarancji postanowień traktatu warszawskiego używali także polscy przeciwnicy elekcji Stanisława Leszczyńskiego. Wywołało to ostrą reakcję Konarskiego i zostało zakwestionowane aktem konfederacji dzikowskiej z 5 listopada $1734 \mathrm{r}^{22}$ Mimo że spór o rosyjską gwarancję polskiego ustroju dotarł do ogółu narodu politycznego, nie znamy przypadków, aby przez następne 20 lat panowania Augusta III dyskusja na ten temat uległa odnowieniu. Nieznane są także przypadki, aby strona rosyjska w tym okresie uzurpowała sobie status gwaranta.

Dopiero schyłek 1754 r., któremu towarzyszyła ostra polaryzacja sceny politycznej w Rzeczypospolitej, przyniósł recydywę kwestii rosyjskiej gwarancji. Osią sporu, który targał polską sceną polityczną, była kwestia dokonanego rok wcześniej (drogą porozumienia z ostatnim ordynatem Januszem Sanguszką) w Kolbuszowej podziału ordynacji ostrogskiej. Przedsięwzięcie od strony technicznej (majątkowej) przygotował zięć wojewody ruskiego, strażnik wielki koronny Stanisław Lubomirski. Jednak najważniejsze były kalkulacje polityczne, które przyświecały przywódcom Familii. Za pomocą transakcji podziałowej zgrupowali oni wokół siebie szeroki blok polityczny („partia kolbuszowska”), do którego zaciągnięci zostali niegdysiejsi konkurenci i wrogowie Czartoryskich, m.in. kanclerz wielki koronny Jan Małachowski, wojewoda smoleński Piotr Sapieha, krajczy koronny Franciszek Salezy Potocki. Po stronie „kolbuszowców” stał również prymas Adam Komorowski. Była to próba przeciwstawienia się rosnącym wpływom marszałka nadwornego koronnego Jerzego Augusta Mniszcha. Udziałowcy przedsięwzięcia bronili jego legalności, co stało się ich podstawową spójnią, ale ich przeciwnicy i ogół szlachecki uważali ten akt za bezprawny. W efekcie scena polityczna podzieliła się na dwa obozy. Z drugiej jej strony stanęła popierana przez dwór (czyli pierwszego ministra saskiego Henryka Brühla) „koalicja antykolbuszowska”, której spoiwem był postulat wprowadzenia administracji państwowej w dobrach ordynacji ostrogskiej.

${ }^{22}$ Z. Zielińska, Echa dokonań, s. 317-319 (tu wcześniejsza literatura). 
W skład koalicji wchodzili trzej hetmani: Jan Klemens Branicki, Michał Kazimierz Radziwiłł i Wacław Rzewuski, liderzy stronnictwa francuskiego Antoni Potocki i Stanisław Świdziński oraz marszałek nadworny koronny Mniszech, wraz z budowanym przez siebie nowym stronnictwem dworskim - „kamarylą". Koalicja dysponowała znaczącą przewagą nad konkurencyjną ,partią kolbuszowską"23.

2 listopada 1754 r. August III wydał reskrypt, mocą którego w ordynacji ostrogskiej została wprowadzona administracja państwowa, co było równoznaczne z zasekwestrowaniem tych dóbr. Powołano administratorów i komisję do ich lustracji. Wywołało to gwałtowny sprzeciw „partii kolbuszowskiej”, dowodzącej, że był to zamach na podstawowe wolności i prawa, gwarantujące nienaruszalność dziedzicznych dóbr ziemskich bez wyroku sądowego. Swoje stanowisko „kolbuszowcy” zawarli w drukowanej broszurze autorstwa Tomasza Dłuskiego pt. Odpowiedź na pytanie, jeżeli by na dobra ostrogskie administracyja uproszona być mogła. Trybunał Koronny, zdominowany przez „koalicję anykolbuszowską”, wydał wyrok nakazujący publiczne spalenie broszury ${ }^{24}$.

Obserwujący rozwój sytuacji politycznej w Polsce dyplomaci: rosyjski Heinrich Gross (Genrih Gross) i brytyjski Charles Hanbury Williams od początku zatargu pisali do swoich stolic relacje pełne zaniepokojenia. Posługując się argumentacją podpowiadaną im przez przywódców Familii i kanclerza Małachowskiego, utrzymywali, że samowładna decyzja króla o wprowadzeniu administracji w dobrach ostrogskich stanowi groźbę dla polskich wolności, co jest skrajnie niebezpieczne dla rosyjskich interesów nad Wisłą i Niemnem. Przy tym wprost utożsamiali polską wolność z bezsiłą Rzeczypospolitej. Zarzucali także dworowi bezprawną rekwizycję dóbr ziemskich oraz dostrzegali zdecydowaną przewage „koalicji antykolbuszowskiej”. O ile jednak Williams przyjął bez zastrzeżeń punkt widzenia „kolbuszowców”, o tyle Gross zwracał uwagę, że sprawa jest delikatna z uwagi na sojusz dworów petersburskiego i drezdeńskiego ${ }^{25}$.

Zgodnie z relacją Grossa, jeszcze przed wprowadzeniem administracji prymas Komorowski odbył audiencję u Augusta III. Bezpośrednim

${ }^{23}$ W. Konopczyński, Polska $w$ dobie, s. 1-14; J. Michalski, Lubomirski Stanisław, PSB, t. 18, Wrocław-Warszawa-Kraków 1973, s. 53; J. Długosz, „Transakcja Kolbuszowska 1753 r.” i jej wewnętrzne skutki polityczne, „Zeszyty Naukowe Uniwersytetu Opolskiego. Historia” 1998, 34, s. 63-70. T. Szwaciński, Finał sejmu 1754 r., s. 163-193.

${ }^{24}$ T. Szwaciński, Finał sejmu 1754 r., s. 174-180, 188.

${ }^{25}$ Ibidem. Rozumienie wolności polskich przez obcych jest bez wątpienia niezwykle ciekawym zagadnieniem godnym pogłębionych studiów, por. rozumienie wolności przez samych Polaków: A. Grześkowiak-Krwawicz, Regina libertas. Wolność w polskiej myśli politycznej XVIII wieku, Gdańsk 2006, passim, w tym kontekście zwłaszcza s. 229-248. 
jej powodem było przedłożenie przez Jerzego Augusta Mniszcha supliki 32 senatorów, proszących o wprowadzenie administracji państwowej w dobrach ostrogskich. Komorowski podkreślił, że traktat warszawski z 1716 r. zabraniał odbywania rad senatu bez odpowiedniej procedury i przypomniał o rosyjskiej mediacji podczas zawierania wspomnianego traktatu. Dokładny opis audiencji został przekazany Grossowi jako donos na bezprawne działanie dworu i przypomnienie traktatu warszawskiego ${ }^{26}$. Z punktu widzenia tytułowych rozważań ma znaczenie fakt, że od czasu konfederacji dzikowskiej jest to pierwszy znany przypadek przywołania roli Rosji w ustawodawstwie lat 1716-1717.

Tydzień później z kolei Williams przekonywał swojego mocodawcę, sekretarza stanu departamentu północnego, Roberta Darcy'ego hr. Holderness, że działania hetmana Branickiego łamią traktat, który został podpisany przez rosyjskiego dyplomatę, a zarazem mediatora Grigorija Dołgorukowa, „co oznacza, że obecna caryca, jest gwarantką, poprzez obowiązek troski o zawarte tam artykuły"27. Co ciekawe, brytyjski dyplomata podał przykład mogący świadczyć, że rosyjska gwarancja postanowień traktatu warszawskiego była uznawana powszechnie, także przez przedstawicieli „koalicji antykolbuszowskiej”. Oto bowiem pewien Żyd, protegowany Brühla, któremu dostarczał towary bez opłaty cła, został skontrolowany przez żołnierzy gwardii nasłanych przez marszałka wielkiego koronnego Franciszka Bielińskiego. Dostawca odwołał się do pierwszego ministra, który wysłał mu na pomoc kilku żołnierzy z kwaterującego w Warszawie regimentu dragonów. Odebrali oni towar ludziom marszałka. Choć wywołało to wiele hałasu, sprawa została załatwiona polubownie. Wszelako Bieliński miał oświadczyć Grossowi, że gdyby nie rozwiązanie konfliktu,

26 „А сколь скоро примас о сем всем здешним правам противном поступке услышал, он себе испросил у ЕВ-а ауденцию, которая ему на другой день, то есть 19/30 сего и дозволилась. Он в ней ЕВ-у в самых сильнейших терминах, хотя со всяким надлежащим респектом, изяснил коль реченное приватное подписание сенаторов некоторых челобитной о государственом деле сопротивляется уставам особливо трактату от 1716 года, под медяцею российскою заключеному, в котором имянно все партикулярныя тайныя сходбища запрещены и не возможно держать Сенатус Консилиума stante pede (скоропостижно без общаго совета и без обыкновеной формы), еще де менше causate pede (с безразсудным поспешением)", H. Gross do Elżbiety, Warszawa, 23 X/3 XI 1754 (rel. nr. 108), AVPRI, f. 79/1, d. 1754/5, k. 237v-238. Williams, także opisujący audiencję, nie wspomniał o naruszeniu traktatu 1716 r.; por. T. Szwaciński, Finał sejmu 1754 r., s. 177-178.

${ }^{27}$ Ch. Hanbury Williams do R. Darcy'ego Holdernessa, Warszawa, 6 XI 1754, TNA SP 88/76, k. 149v.-151; por. T. Szwaciński, Finał sejmu 1754 r., s. 185-186. W relacji Williams poruszył sprawę potwierdzenia detronizacji Leszczyńskiego traktatem 1716 r., co było jakoby podstawą rosyjskiej interwencji w $1733 \mathrm{r}$. Na ten temat por. Z. Zielińska, Echa dokonań, s. 318. 
zmuszony byłby zażądać od dyplomaty wypełnienia przez carycę Elżbietę gwarancji wynikającej z traktatu warszawskiego ${ }^{28}$. Zapewne chodziło o bezprawne użycie wojsk saskich w Polsce. Konkretna ta sprawa wymaga jednak dodatkowego potwierdzenia źródłowego, można bowiem przypuszczać, że faktografia w tym przypadku została zniekształcona.

Także Gross poruszył sprawę użycia w Rzeczypospolitej saskich wojsk, wpisując ją w kontekst naruszenia postanowień traktatu $1716 \mathrm{r}$. Sytuacja w Polsce, jak relacjonował dyplomata, mogła doprowadzić do zamieszek, w które by zaangażowano obce mocarstwa. Szczególnie dowodził - dotyczyło to Rosji, która zostałaby wezwana przez jedną $\mathrm{z}$ walczących stron. Podstawą tego miał być trakt warszawski $1716 \mathrm{r}$., zawarty przy mediacji rosyjskiej. Gross donosił także, że odradzał Sanguszce wysłanie supliki do Petersburga, w której marszałek nadworny litewski skarżyłby się na prześladowania i naruszenie traktatu warszawskiego. Dyplomata przedstawiał to jako element szerszej polityki, nastawionej na deeskalację napięć na polskiej scenie politycznej i zachowanie spokoju wewnętrznego ${ }^{29}$.

Relacje Grossa i Williamsa ukazują złożoność problemu. Najważniejszą kwestią była różnica między pojęciem „gwarancja”, używanym przez Williamsa, i „mediacja”, którym posługiwał się Gross. Nie wydaje się, aby mógł to być przypadek. Czartoryscy, przestraszeni wymierzoną w siebie akcją politycznych przeciwników, postanowili zaapelować o pomoc Rosji, formułując tezę o gwarantowaniu przez Petersburg polskiego ustroju. Skoro dwór polski złamał prawo, imperium musiało interweniować. Ich słowa znalazły wyraźne odbicie w relacjach Williamsa. Natomiast Gross, mimo że opowiedział się po stronie Familii i potępił wprowadzenie administracji w ordynacji, rozumiał potrzebę zachowania dobrych relacji Petersburga z Dreznem. Zapewne to sprawiło, że w pierwszych tygodniach po sejmie $1754 \mathrm{r}$. powstrzymywał się od używania terminu „gwarancja”. Trzeba zatem uznać, że dyplomaci brytyjski i rosyjski oraz współpracujący z nimi przywódcy Familii doskonale rozumieli, jak brzemienny w skutkach mógł być sposób dobierania przez nich argumentacji.

W relacji z 11 listopada $1754 \mathrm{r}$. Williams, relacjonując politykę rozdawniczą dworu sasko-polskiego, stwierdził, że spotka się ona z niezadowoleniem w Petersburgu. Ponadto przypuszczał, że Brühl, żywiąc obawy przed reakcją Rosji na swoje działania w Polsce, wysłał nad Newę

${ }^{28}$ Ch. Hanbury Williams do R. Darcy'ego Holdernessa, Warszawa, 6 XI 1754, TNA SP 88/76, k. 151v.-152.

${ }^{29}$ H. Gross do Elżbiety, Warszawa, 30 X/10 XI 1754 (rel. nr. 110), AVPRI, f. 79/1, 1754/5, k. 283-285; por. T. Szwaciński, Finał sejmu 1754 r., s. 187, 189. 
i Tamizę pisma oczerniające „partię kolbuszowską”. Pierwszy minister mógł także wmawiać Petersburgowi i Londynowi, że to Gross i Williams podjudzali Familię do opozycji wobec Augusta III ${ }^{30}$. Jednocześnie deklaracje składane brytyjskiemu dyplomacie przez przywódców „partii kolbuszowskiej" mówiły o ich twardej woli utrzymania spokoju wewnętrznego w kraju, a także cierpliwego czekania na stanowisko Petersburga. Rosja była bowiem - co podkreślali Czartoryscy - gwarantką polskich wolności i nie mogła dopuścić do opresji obywateli ze strony hetmanów. Wszelako „w przypadku skrajnej konieczności” przywódcy Familii ostrzegali, że będą musieli podjąć stanowcze działania ${ }^{31}$.

17 listopada Gross i Williams odbyli długą rozmowę. Wedle tego ostatniego zgodzili się w ocenie niebezpieczeństw związanych z polskim kryzysem. Obawiali się, że Mniszech zamierza rządzić Polską równie despotycznie, jak czynił to Brühl w Saksonii, a pierwszy minister, jeżeli był na żołdzie Francji i Prus, realizowałby w Rzeczypospolitej politykę zgodną $\mathrm{z}$ interesami tych państw ${ }^{32}$. Wydaje się, że w tym przypadku Walijczyk zagalopował się w oskarżeniach Brühla o porzucenie dotychczasowego systemu sojuszy. Znacznie bardziej wyważony Gross nie zdecydował się na raportowanie takich zarzutów. Różnice w przekazie obu dyplomatów widać także w nieco innym przypadku. Sprawą, która niepokoiła ich obu, było ewentualne wmieszanie się w polski kryzys obcych, wrogich mocarstw: Turcji, Francji i Prus. Wszelako Gross cały czas traktował Drezno jako naturalnego sojusznika oraz liczył na jego wsparcie w zwalczaniu wersalskich intryg w Konstantynopolu i kontaktów hetmana Branickiego z dworem arcychrześcijańskim. Można przyjąć, że Brühl rozumiał bardziej wyważoną (realistyczną) postawę rosyjskiego dyplomaty i starał się ją zdyskontować. Przekonywał bowiem za pośrednictwem Grossa dwór petersburski, że rosyjska ingerencja w sprawy polskie nie była potrzebna, tym bardziej że przyniosłaby szkody w postaci francuskiej lub tureckiej kontrakcji ${ }^{33}$.

${ }^{30}$ Ch. Hanbury Williams do R. Darcy'ego Holdernessa, Warszawa, 11 XI 1754, TNA SP 88/76, k. 221-229v.; por. D.B. Horn, op. cit., s. 169-170. O podjęciu akcji propagandowej przez Brühla w Petersburgu i Londynie zaraz po zerwaniu sejmu milczy Konopczyński, jednak autor Polski $w$ dobie wojny siedmioletniej rozpoczął kwerendę korespondencji Drezna z saskimi dyplomatami w Petersburgu (Johann Ferdinand August von Funcke) i Londynie (Carl Ludwig Wiedmarck) od 1755 r.

${ }^{31}$ Ch. Hanbury Williams do R. Darcy'ego Holdernessa, Warszawa, 18 XI 1754, TNA SP 88/76, k. 256-256v.

${ }^{32}$ Ibidem, k. 258-258v.

${ }^{33}$ H. Gross do Elżbiety, Warszawa, 6/17 XI 1754 (rel. nr 111), AVPRI, f. 79/1, d. 1754/5, k. 293-294; Ch. Hanbury Williams do R. Darcy'ego Holdernessa, Warszawa, 18 XI 1754, TNA SP 88/76, k. 257-257v. 
W połowie listopada 1754 r. Gross donosił, że spór o ordynację ostrogską chwilowo przycichł, jednak, wedle dyplomaty, w związku z rychłym otwarciem prac komisji do lustracji dóbr ordynacji, która procedować miała w Dubnie, wątpliwe było, aby taki stan długo się utrzymał. Punktem zapalnym mogły być obawy szlachty osiedlonej w dobrach ostrogskich przez Janusza Sanguszkę przed uznaniem jej przywilejów za nieprawne. Potęgowało się także rozgoryczenie przywódców Familii. Nie ustawało bowiem ich szykanowanie ze strony Mniszcha i hetmana Branickiego. August Czartoryski został pozwany przez hetmana przed trybunał skarbowy w Radomiu pod zarzutem bezprawnego wykorzystania pieniędzy na pułk piechoty gwardii koronnej, co miało być pretekstem do pozbawienia wojewody ruskiego dowództwa nad tą jednostką (sprawowanego od 26 lat). Jak donosił Gross, komenda nad gwardią miała szczególne znaczenie, bowiem w przypadku bezkrólewia oddział ten, jako jedyny, miał prawo przebywania na polu elekcyjnym. Jednocześnie sojusz Mniszcha, Branickiego i stronników francuskich z Antonim Potockim na czele, zdaniem Grossa, działał sprawnie, a dwór kontynuował rozdawnictwo łask za rekomendacją dyplomacji króla arcychrześcijańskiego. Takie wzmacnianie przez dwór sasko-polski partii francuskiej stało się zarzewiem plotek o chęci uzyskania przez Drezno francuskich subsydiów. Szeptano także o mariażu księcia Ksawerego z córką króla francuskiego, co miało się wiązać z widokami na poparcie dworu wersalskiego w ewentualnych staraniach o koronę polską. Zgodnie z wyważonym tonem swych relacji rosyjski dyplomata uznawał te pogłoski za bezpodstawne, suponując, że bezpośrednim powodem zbliżenia Mniszcha z partią francuską była ich wspólna nienawiść do Czartoryskich, a także nieokiełznana żądza władzy marszałka nadwornego, który widział już siebie w roli przywódcy potężnego, szerokiego stronnictwa. Miał on, zdaniem Grossa, liczyć, że magnaci orientacji profrancuskiej stopniowo ujawnią przed nim sekretne działania dyplomacji francuskiej dotyczące sukcesji polskiej, które stały w sprzeczności z interesem Brühla i domu Wettynów. Jak zauważał dyplomata, było mało prawdopodobne, aby Francja, pomimo oficjalnych zapewnień, zrezygnowała z forsowania kandydatury burbońskiej na tron polski. Gross dowiedział się także, że postanowiono na dworze, aby Mniszech nie wracał z królem do Drezna, ale pozostał w Rzeczypospolitej wyposażony w nadzwyczajne pełnomocnictwa w celu przeciwdziałania ewentualnym akcjom, które byłyby wymierzone w decyzję królewską o wprowadzeniu administracji w dobrach ostrogskich. Mimo to tydzień później dyplomata, przekazując zdobyte przez siebie dokumenty dotyczące sprawy 
ordynacji, donosił, że do tej pory nie wywołała ona gwałtownej kontrakcji ze strony pokrzywdzonych ${ }^{34}$.

Ostrzeżenia o zbliżeniu Drezna i Wersalu (z polską i kurlandzką sukcesją w tle) przedstawiali także Williamsowi kasztelan krakowski Stanisław Poniatowski i kanclerz koronny Jan Małachowski. Walijczyk (w przeciwieństwie do Grossa) podszedł do owych rewelacji nadzwyczaj poważnie $e^{35}$. Uznał, że sekretne plany są dziełem Brühla. Wedle dyplomaty „wiele osób” (z pewnością informatorami byli znów przywódcy „partii kolbuszowskiej”) uważało, że pierwszy minister, planując osadzenie na tronie polskim królewicza Ksawerego, sam widział się w roli księcia kurlandzkiego. Dyplomata podkreślał jednak zdecydowanie, że informacje dotyczące tej sprawy wymagają jeszcze potwierdzenia. Zobowiązał się przeprowadzić możliwie skuteczny wywiad ${ }^{36}$, który (za sprawą informacji pozyskanych od szczególnie bliskiego Familii dygnitarza saskiego Ferdinanda Ludwiga Saula) przyniósł uspokajające nowiny. Dwór drezdeński nie zamierzał wchodzić w orbitę Wersalu ${ }^{37}$.

${ }^{34}$ Nowym przejawem łaski dworskiej okazywanej „koalicji antykolbuszowskiej” było mianowanie starosty ciechanowskiego Andrzeja Mokronowskiego generałem inspektorem jazdy, a starosty radomskiego Kazimierza Granowskiego (zięcia nowego wojewody rawskiego Świdzińskiego) generałem inspektorem piechoty. Wyznaczone im wynagrodzenie (dwie porcje od każdej roty) było, wedle relacji Grossa, sprzeczne z postanowieniami konstytucji 1717 r., H. Gross do Elżbiety, Warszawa, 6/17 i 13/24 XI 1754 (rel. 115, 118), AVPRI, f. 79/1, 1754/5, k. 313-314v., 330-330v. Por. T. Ciesielski, Armia koronna, s. 57-58. Właściwe oszacowanie wpływu dyplomacji francuskiej (jawnej i sekretnej) na przemiany polskiej sceny politycznej w $1754 \mathrm{r}$. oraz zdefiniowanie planów i nadziei Wersalu w tym obszarze wymaga krytycznego studium opartego o systematyczną kwerendę źródeł przechowywanych nad Sekwaną. Fakt, że „dyplomaci francuscy głosili urbi et orbi rozbicie przeciwników" (listopad 1754 r.), sprawia, że łatwo tu o nadinterpretację, J. Nieć, Młodość ostatniego elekta. St. A. Poniatowski 1732-1764, Kraków 1935, s. 109. Patrz też: K. Waliszewski, Potoccy i Czartoryscy. Walka stronnictw i programów politycznych przed upadkiem Rzeczypospolitej, 1734-1763, t. 1: 1734-1754, Kraków 1887, s. 186-236. Na temat polityki zagranicznej Brühla w tym okresie por: R. Hanke, Brühl und das Renversement des alliances. Die antipreußische Außenpolitik des Dresdener Hofes 1744-1756, Berlin 2006, s. 255-291.

${ }^{35}$ Ch. Hanbury Williams do R. Darcy'ego Holdernessa, Warszawa, 18 XI 1754, TNA SP 88/76, k. 252-256. Brytyjski dyplomata pozostawał w bliskich stosunkach z rodziną Poniatowskich przez przyjaźn ze starostą przemyskim Stanisławem Antonim Poniatowskim, R. Butterwick, Stanisław August a kultura angielska, Warszawa 2000, s. 103-117 (oryg. ang. 1998). Dodajmy, że cytowana wyżej relacja Williamsa raczej nie może być dowodem na to, że kasztelan Poniatowski „wycofał się z polityki”, por. J. Nieć, op. cit., s. 109.

${ }^{36}$ Ch. Hanbury Williams do R. Darcy'ego Holdernessa, Warszawa, 28 XI 1754, TNA SP 88/76, k. 269v.-270.

37 Ch. Hanbury Williams do R. Darcy'ego Holdernessa, Warszawa, 12 XII 1754, TNA SP 88/76, k. 299v.-300. Definitywne rozwianie wszelkich obaw Williamsa związanych 
27 listopada Zofia z Krasińskich (primo voto Janowa Tarłowa), żona wojewody lubelskiego Antoniego Lubomirskiego, odbyła rozmowę z dyplomatą francuskim Charles'em François hr. Broglie, którą trzy dni później zrelacjonowała Grossowi i Williamsowi. Jako żona uczestnika transakcji kolbuszowskiej skłaniała się ku prorosyjskiej orientacji „partii kolbuszowskiej”, mimo swej republikanckiej przeszłości. Wedle relacji Grossa, Francuz chwalił się, że nigdy wcześniej dyplomacja francuska nie miała takich sukcesów w zwalczaniu partii rosyjskiej w Rzeczypospolitej. Broglie przy tym utrzymywał, że gdyby na minionym sejmie doszło do wyboru marszałka, sąd sejmowy odsunąłby Michała Czartoryskiego od urzędu kanclerskiego ${ }^{38}$. Natomiast zgodnie z relacją Williamsa, Lubomirska zwierzyła się obu dyplomatom, że Broglie zapewniał ją, iż administracja w dobrach ostrogskich została wprowadzona wbrew stanowisku Brühla, a wspólnym staraniem jego samego i Mniszcha, którzy przekonali do tego króla ${ }^{39}$. Widać zatem, że relacje Grossa i Williamsa, dotyczące informacji przekazanych im przez wojewodzinę, różnią się między sobą. Walijczyk donosił „na żywo”, rosyjski dyplomata nie spieszył się i przekazał informacje dopiero po dwóch tygodniach. To, co Williams uznał za godne uwagi (sprzeciw Brühla wobec administracji), Gross w ogóle pominął, uważając zapewne za zupełnie niedorzeczne. Trzeba przy tym podkreślić przewagę rosyjskiego dyplomaty w krytycznej i prawidłowej analizie sytuacji na polskiej scenie politycznej.

W tym czasie Gross złożył wizytę Brühlowi, gdzie zastał kanclerza Małachowskiego. Dyplomata zamierzał wyjaśnić informację o planowanej przez dwór radzie senatu i uprzedził, że jeżeli istotnie odbędzie się posiedzenie, to on przedstawi na tym forum postulaty swojego dworu dotyczące zbiegostwa chłopów, wynagrodzenia dla polskich komisarzy pogranicznych oraz tytułu imperatorskiego władców Rosji. Były to stałe elementy, które rosyjscy dyplomaci przedkładali na sejmach

z intrygami dyplomaty francuskiego Charles'a Broglie z królową polską Marią Józefą nastąpiło w połowie stycznia następnego roku, Ch. Hanbury Williams do R. Darcy'ego Holdernessa, Drezno, 15 I 1754, TNA SP 88/77, k. 32-32v.

${ }^{38}$ H. Gross do Elżbiety, Warszawa, 3/14 XII 1754 (rel. nr 130), AVPRI, f. 79/1, d. $1754 / 5$, k. 422.

39 Ch. Hanbury Williams do R. Darcy'ego Holdernessa, Warszawa, 2 XII 1754, TNA SP 88/76, k. 273-274v.; por. D.B. Horn, op. cit., s. 169. Historyk bezkrytycznie traktuje informacje Lubomirskiej przekazane Williamsowi. Jeszcze półtora miesiąca później Williams przypominał zwierzenia Lubomirskiej jako koronny dowód na francusko-pruską inspirację wydarzeń w Polsce, Ch. Hanbury Williams do R. Darcy'ego Holdernessa, Drezno, 15 I 1755, TNA SP 88/77, k. 25. 
i posejmowych radach senatu, jednak Brühl i Małachowski obawiali się, że wystąpienie rosyjskiego dyplomaty skomplikuje obrady. Zwłaszcza ostatni punkt wywołał ich zgodny opór, bowiem podkreślili, że decyzję o uznaniu tytułu imperatorskiego władny był podjąć jedynie sejm. Gross przyjął tę argumentację, a relacjonując sprawę swojemu dworowi, dodał od siebie, że przy obecnym ostrym konflikcie politycznym w gronie senatorów należało obawiać się oporu wobec takiej decyzji, zwłaszcza jeśliby wziąć pod uwagę groźbę zdominowania zgromadzenia przez stronników Francji. Jak dowiedział się dyplomata z innych źródeł, głównym motywem ewentualnego zwołania rady senatu było zwrócenie hetmanowi Branickiemu kosztów podejmowania orientalnych emisariuszy, zatem miała mieć ona wyłącznie „techniczny” charakter. Natomiast Williams żywił daleko idące, choć niesprecyzowane (,there is something brewing") podejrzenia wobec motywów, które skłoniły dwór do zwołania rady senatu. Do obrad jednak nie doszło. Powodem zmiany decyzji dworu miały być obawy, że senatorowie wyjdą w swych głosach poza wyznaczoną przez króla problematykę i powrócą do sprawy ostrogskiej. Pozostawały jednak roszczenia hetmana Branickiego, który, wedle agenta Michała Kazimierza Radziwiłła, Andrzeja Protasowicza, „na pokojach rzekł to był: «co to jest za stateczność dworu, kiedy wczoraj tak, dziś inaczej intencje swoje względem senatus consilium ogłasza», i w tej irytacyi z pokojów był odjechał" ${ }^{40}$. Warto podkreślić, że Gross nie dostrzegł (bądź nie uznał za wskazane donieść do Petersburga) tej pierwszej jaskółki konfliktu w łonie „koalicji antykolbuszowskiej”. Ostatecznie Branicki za utrzymanie orientalnych emisariuszy otrzymał 142 tys. zł na podstawie reskryptu królewskiego i asekuracji podpisanej przez obecnych w Warszawie senatorów, że będą się starali o zaakceptowanie tej kwoty przez najbliższy sejm ${ }^{41}$. W swoich raportach do Petersburga Gross ubolewał, że dwór szedł na konfrontację w sprawie broszury wydanej w drukarni pijarskiej pt. Odpowiedź na pytanie, jeżeliby na dobra ostrogskie administracja uproszona być mogła i dążył do jej publicznego spalenia ${ }^{42}$. Było to wyraźnym dowodem napięcia utrzymującego się na

${ }^{40}$ H. Gross do Elżbiety, Warszawa 20 XI/1 XII 1754 (rel. nr 123), AVPRI, f. 79/1, 1754/5, k. 385-386; Ch. Hanbury Williams do R. Darcy'ego Holdernessa, Warszawa, 28 XI 1754, TNA SP 88/76, k. 271-271v.; A. Protasowicz do M.K. Radziwiłła, Warszawa, 1 XII 1754, AGAD, Archiwum Radziwiłłów (dalej: AR) V, sygn. 12416/IV, s. 174-175.

${ }^{41}$ H. Gross do Elżbiety, Warszawa, 27 XI/8 XII i 3/14 XII 1754 (rel. nr 127, 131), AVPRI, f. 79/1, 1754/5, k. 409-409v., 434.

${ }^{42}$ H. Gross do Elżbiety, Warszawa, 27 XI/8 XII 1754 (rel. nr 127), AVPRI, f. 79/1, $1754 / 5$, k. 409v. W sprawie wspomnianej broszury patrz: T. Szwaciński, Finał sejmu 1754 r., s. 174-175, 178, 188, tu wcześniejsza literatura. 
polskiej scenie politycznej i nieustającej opresji „partii kolbuszowskiej” ze strony władzy.

1 grudnia 1754 r. przybył do Warszawy kurier z informacją od biskupa krakowskiego Andrzeja Stanisława Załuskiego, że 26 listopada w Dubnie komisja lustracyjna spokojnie rozpoczęła prace, mimo iż Janusz Sanguszko złożył protest przeciwko temu aktowi. Jak donosił Gross, jedynym przejawem kontrakcji ze strony udziałowców kolbuszowskich było rozsiewanie opinii, że wszystkie dochody z ordynacji zostaną obrócone na potrzeby administratorów i komisarzy, książę Sanguszko zaś i Rzeczpospolita w żaden sposób nie będą profitować. Ponadto przypuszczano, że dwór na następnym sejmie nadzwyczajnym będzie się starał przekazać część dóbr ostrogskich zakonowi maltańskiemu ${ }^{43}$. Przed samym wyjazdem do Drezna Gross donosił o planowanym już w następnym roku sejmie nadzwyczajnym, którego celem miało być ostateczne uregulowanie sprawy ostrogskiej, po zakończeniu prac komisji. Tak rychły termin zwołania zgromadzenia zaskoczył dyplomatę, a wiele osób (w relacji wymienił podkanclerzego koronnego Michała Wodzickiego) uznawało, że uniwersały przedsejmowe miały pozostawać jedynie w rezerwie na wypadek zamieszek. Gross jednak dowodził, że środek zapobiegawczy w postaci groźby zwołania sejmu nadzwyczajnego mógłby odnieść spodziewany skutek, jeżeliby ze strony dworu poczynione zostały przyjazne kroki wobec „partii kolbuszowskiej”. W rzeczywistości podejmowane przez dwór działania były konfrontacyjne i prowadziły do dalszego zaostrzenia sytuacji. Wymownym tego przykładem było spalenie w Piotrkowie wspomnianej broszury (Odpowiedź na pytanie...) oraz opieczętowanie drukarni pijarów. Jednocześnie hetman Branicki cieszył się opieką dworu, co ośmieliło go do wytoczenia pozwu podstolemu koronnemu Stanisławowi Lubomirskiemu za antyhetmański manifest wydany przez tego ostatniego osiem miesięcy wcześniej. Z kolei żaden gród nie chciał przyjąć manifestu Janusza Sanguszki, obawiając się represji. Obok tego Familia była konsekwentnie dyskryminowana w rozdawnictwie łask. Sytuacja skłaniała Czartoryskich do ciągłych pytań o stanowisko Rosji wobec wydarzeń w Polsce. Przywódcy Familii argumentowali, że wprowadzenie tu absolutyzmu było sprzeczne z interesami Petersburga.

${ }^{43}$ H. Gross do Elżbiety, Warszawa, 20 XI/1 XII i 27 XI/8 XII 1754 (rel. nr 123, 127), AVPRI, f. 79/1, d. 1754/5, k. 386, 409v.-410; A. Protasowicz do M.K. Radziwiłła, Warszawa, 1 XII 1754, AGAD, AR V 12416/IV, k. 172-174; por. T. Szwaciński, Raporty Udalryka Radziwiłta do ambasady rosyjskiej o pracach komisji dubieńskiej (styczeń-marzec 1755 r.), w: Нясвіжскі замак. Падзеі, асобы, спадчына. Матэрыялы Міжннароднай навуковай канферэнцы, прысвечанай 435-годдзю пачатку будаўніизтва Нясвіжскага замка (Нясвіж, 6-7 верасня 2018 г.), Нясвіж 2019, s. 182-203. 
Pozbawiony instrukcji, a nagabywany przez książąt Gross coraz natarczywiej prosił swój dwór o odpowiednie wytyczne ${ }^{44}$.

Natomiast wedle Williamsa zdeterminowani przywódcy „partii kolbuszowskiej" żądali rosyjskiego wsparcia, powołując się na traktaty. Mieli deklarować gotowość do zdecydowanych kroków (konfederacji), od których w większym stopniu powstrzymywała ich obawa przed negatywną reakcją ze strony Rosji niż wzgląd na własny dwór. Dyplomata brytyjski ponownie upewniał Londyn, że wraz z Grossem podjęli skuteczne starania, aby zachować w Rzeczypospolitej spokój. Obaj dyplomaci zapewniali także polskich rozmówców, że caryca Elżbieta gwarantowała nienaruszalność polskiego ustroju ${ }^{45}$. Około 10 grudnia $1754 \mathrm{r}$. Czartoryscy odbyli długą rozmowę z Williamsem. Książęta zobowiązywali się do cierpliwego oczekiwania na stanowisko Petersburga. Jeżeliby Rosja pozostała bierna, zamierzali prosić dwór londyński, aby interweniował w Petersburgu na ich rzecz. W ostateczności planowali wysłać do Petersburga własnego posłańca, który prosiłby carycę o gwarancję bezpieczeństwa i protekcję ${ }^{46}$.

Przed samym swoim wyjazdem z Warszawy do Drezna (14 XII 1754 r.) Gross złożył prymasowi pożegnalną wizytę. U Komorowskiego zastał obu braci Czartoryskich. Korzystając z okazji, cała trójka po raz kolejny zadeklarowała, że „ze skrajną niecierpliwością” oczekuje reakcji Elżbiety na przewrót, który dokonał się w Polsce. Odwołując się do traktatu warszawskiego z 1716 r., którego caryca była - jak utrzymywali - gwarantką, wyrażali nadzieję, że władczyni Rosji nie będzie obojętnie patrzeć na działania stanowiące naruszenie owego traktatu i zmierzające do złamania

${ }^{44}$ Sekretarz litewski Antoni Wołłowicz został mianowany koadiutorem łuckim, mimo że godność ta od lat była obiecana protegowanemu Familii Hieronimowi Szeptyckiemu, któremu Kajetan Sołtyk wprost miał oświadczyć, że August III nie zamierzał dotrzymywać zobowiązań danych Czartoryskim i ludziom ich stronnictwa. Niemal identyczną deklarację usłyszał z tych samych ust Ignacy Massalski. H. Gross do Elżbiety, Warszawa, 3/14 XII 1754 (rel. nr 130), AVPRI, f. 79/1, d. 1754/5, k. 421-422v.; Uniwersał Augusta III zwołujący sejm nadzwyczajny, b.d. (załącznik „A” do rel. Grossa nr 130/1754), ibiedm, k. 429-430. W latach 1751-1752 o biskupstwo dla Szeptyckiego upominała się Familia m.in. za pośrednictwem Williamsa, Ł. Galas, Szeptycki Hieronim Antoni, PSB, t. 48, Warszawa-Kraków 2012, s. 233. Patrz też: T. Szwaciński, Walka „Familii” o koadiutorię wileńską: 1754-1757, w: W cieniu wojen i rozbiorów, s. 199-201.

${ }^{45}$ „We do not deny but that they are entitled to the guarantee at Russia, and M. Gross assures them that the empress of Russia has very much at heart the preservation of the liberties and present constitution of Poland, and that her own interest demands they should not be infringed or altered", Ch. Hanbury Williams do R. Darcy'ego Holdernessa, Warszawa, 2 XII 1754, TNA SP 88/76, k. 276-277.

${ }^{46}$ Ch. Hanbury Williams do R. Darcy'ego Holdernessa, Warszawa, 12 XII 1754, TNA SP 88/76, k. 296-297v. 
polskich wolności. Gross zasłonił się brakiem instrukcji, ale zapewniał, że zachowanie polskiej wolności, jako część „naturalnych interesów rosyjskich", było przedmiotem zainteresowania carycy Elżbiety, która nigdy nie mogłaby dopuścić do wprowadzenia w Polsce absolutyzmu ${ }^{47}$. W tym miejscu warto zwrócić uwagę, że po raz pierwszy Gross użył w relacji terminu „gwarancja”. Zapewne zaczął dokładnie cytować książąt (co od początku robił Williams), gdy dowiedział się o ich zamiarze nawiązania bezpośredniej korespondencji z Petersburgiem.

W momencie wyjazdu Grossa z Warszawy padła także ze strony obozu Jerzego Augusta Mniszcha pierwsza sugestia o pragnieniu uzyskania rosyjskiej akceptacji dla działań „kamaryli”. Została ona złożona przez koadiutora kijowskiego Kajetana Sołtyka, jednak Gross nie przywiązywał do owego gestu większej wagi, choć dokładnie opisał go w relacji ${ }^{48}$. Niemal równolegle hetman Branicki (za pośrednictwem żony, Izabeli z Poniatowskich) zwrócił się do Williamsa z prośbą o wysondowanie Grossa w sprawie szans uzyskania najwyższego rosyjskiego odznaczenia, tj. Orderu św. Andrzeja. Obaj dyplomaci (o czym Gross milczał w relacjach) odpowiedzieli suplikantowi, że brak pomyślnej decyzji w tej sprawie był efektem złego (profrancuskiego) postępowania hetmana w okresie ostatnich dwóch lat. Williams przypomniał ponadto hetmanowi, że traktat warszawski z 1716 r. dawał Rosji prawo do ingerowania w wewnętrzne sprawy Rzeczypospolitej, w szczególności w przypadku bezprawnego postępowania hetmanów wielkich. Branicki wyglądał na zupełnie zaskoczonego, ale obiecał wziąć to pod uwage ${ }^{49}$.

16 grudnia 1754 r., po wysłuchaniu porannej mszy św. odprawionej przez prymasa, August III opuścił Warszawę, udając się do Drezna. Jak zauważył agent hetmana Radziwiłła, „notandum, że na tym rannym Najjaśniejszego Państwa pożegnaniu nie byli przytomnemi w pałacu ani książę jmść kanclerz wielki WKsL [M.F. Czartoryski], ani Jo książę jmść

47 „От всех троих мне засвидетельствовано, что они с крайним нетерпением ожидают ведать ВИВа сентименты о случившейся перемене дел в их отечестве, не могучи де сумневаться, что по силе трактата варшавского от 1716 года, будучи их гарантом их конституции не можете смотреть с индиферентностию на поступки кои прямо содержанию сего трактата противны и клонятся к совершенному уничтожению польской вольности", H. Gross do Elżbiety, Drezno, 12/23 XII 1754 (rel. nr 134), AVPRI, f. 79/1, d. 1754/5, k. 476-476v.

${ }^{48}$ Ibidem, k. 476v.-477. Por. T. Szwaciński, Władysław Konopczyński o szpiegu pruskim Lambercie. Pytania o orientację zagraniczna Jerzego Augusta Mniszcha, w: Władysław Konopczyński jako badacz dziejów XVIII wieku, red. Z. Zielińska, W. Kriegseisen, Warszawa 2014, s. 103.

${ }^{49}$ Ch. Hanbury Williams do R. Darcy'ego Holdernessa, Warszawa, 25 XII 1754, TNA SP 88/76, k. 310-312. 
wojewoda ruski [A.A. Czartoryski]"50. Dwór zatem opuszczał Rzeczpospolitą, pozostawiając polski kryzys nierozwiązanym. Dwa dni wcześniej nad Łabę pospieszył Gross ${ }^{51}$, natomiast Williams pozostał jeszcze dwa tygodnie w Warszawie ${ }^{52}$.

Wbrew deklaracjom o cierpliwym czekaniu na stanowisko, które w sprawie polskiego kryzysu zajmie Rosja, Michał i August Czartoryscy 19 i 20 grudnia 1754 r. napisali listy do kanclerza Aleksego Bestużewa-Riumina (Aleksej Bestužev-Rûmin), prosząc kierownika rosyjskiej polityki zagranicznej o protekcję i interwencję na ich rzecz. Kanclerz litewski podkreślał, że sytuacja była bardzo groźna dla wolności Rzeczypospolitej, w szczególności dla bezpieczeństwa obywateli. Niezachwiana gorliwość Familii o interesy króla i ojczyzny wywołała niechęć ze strony tych, którzy posiadali odmienne poglądy lub lekceważyli zagrożenia. Michał Czartoryski donosił, że wiedział, iż z gabinetu saskiego zostały wysłane do Petersburga oskarżenia pod adresem Familii, jednakże prawdziwa relacja usprawiedliwić miała działania stronnictwa. Wynikało to z faktu schlebiał kanclerz litewski rosyjskiemu dygnitarzowi - że dwór rosyjski był sprawiedliwy i oświecony, a jego ministerstwo mądre i zapobiegliwe w staraniach o interes imperium. Determinowało to obronę praw i wolności Polaków, gwarancję których przyjął na siebie Piotr Wielki w momencie, gdy został mediatorem traktatu warszawskiego $1716 \mathrm{r}$. Zapewniał także Czartoryski o swojej niezachwianej i świadomej prorosyjskiej postawie, która wynikała z troski o pomyślność Rzeczypospolitej. Na koniec wyraził najwyższe uznanie dla osobistych cnót i profesjonalnych umiejętności Heinricha Grossa. Bardziej odpowiedniego rosyjskiego ministra przy dworze sasko-polskim trudno sobie było wyobrazić; cieszył się on zaufaniem i przyjaźnią zdrowej części narodu („la confiance et l'amitié de la saine partie de la nation") ${ }^{53}$. W datowanym dzień później

50 A. Protasowicz do M.K. Radziwiłła, Warszawa, 17 XII 1754, AGAD, AR V 12416/V, S. $16-18$.

${ }^{51}$ H. Gross do Elżbiety, Drezno, 12/23 XII 1754 (rel. nr 133), AVPRI, f. 79/1, d. 1754/5, k. 474.

${ }^{52}$ Ch. Hanbury Williams do R. Darcy'ego Holdernessa, Warszawa, 16 XII 1754, TNA SP 88/76, k. 302.

53 „Je suis averti que du cabinet Saxon, l'on a envoyé à St. Petersbourg des incusations à notre charge la véritable et l'entière notice de tous les faits et de leurs rapports, fera notre très avantageuse justification, auprès d'une cour équitable, et si parfaitement éclairée, auprès de son ministère si sage et si attentif à l'intérêt naturel de l'Empire de Russie, dans le maintien des droits et des libertés de la nation Polonaise, dont Pierre le Grand a pris sur lui la garantie, lorsqu'il a été médiateur du traité de Varsovie en l'an 1716. Je prie Votre Excellence qu'elle me rende la justice, et me fasse la grâce d'être persuadée, que ce principe est fixé en moy, du bonheur et de l'indemnité de ma patrie, 
liście wojewoda ruski podkreślił także, że motywem napisania listu była akcja propagandowa przeciwników, którzy próbowali oczernić Familię nad Newą. Liczył, że jego oddanie Rosji, jest na tyle wypróbowane, że nie wzbudzi wątpliwości. W odróżnieniu od brata, książę August nie oczerniał gabinetu saskiego. Natomiast stwierdził, że działania dyplomacji francuskiej i pruskiej oraz ludzi tworzących partię francusko-pruską w Rzeczypospolitej w ówczesnym stanie spraw polskich okazały się na tyle gwałtowne, iż to właśnie z tego źródła płynęły oskarżenia pod adresem Familii. Dlatego liczył na protekcję carycy Elżbiety, tym bardziej że bez trudności mógł udowodnić, iż działania jego stronnictwa służyły zachowaniu praw i wolności Rzeczypospolitej, które były umocowane rosyjską gwarancją, przynosząc korzyść obu państwom ${ }^{54}$.

Wedle relacji Williamsa przed zapieczętowaniem książęta pokazali mu pisma. Brytyjski dyplomata zgodnie z prawdą donosił, że wiązały one inicjatywę książąt ze skargami na Familię wysłanymi do Petersburga przez Brühla. Jednak błędnie informował swój dwór, że książęta odwoływali się do obietnicy Anny Iwanowny z 1734 r. wzięcia ich rodziny w rosyjską protekcję $e^{55}$. Niezgodna z prawdą relacja brytyjskiego dyplomaty rodzi

dans les plus intimes liaisons avec l'Empire de Russie et que dans ces sentiments ma conduite à cet égard ne peut être ébranlée ni altérée par aucune fâcheuse personnalité", M.F. Czartoryski do A.P. Bestużewa-Riumina, Warszawa, 19 XII 1754 (tekst pisany cudzą ręką, podpis autograf M.F. Czartoryskiego), AVPRI, f. 79/1, d. 1754/2, k. 32-33v.; tłumaczenie tegoż na rosyjski z prezentą 14/28 I 1755, ibidem, k. 38-39v. Chciałbym podziękować dr. Jackowi Kordelowi za pomoc w uzyskaniu tego i poniższego źródła.

54 „La protection de Sa Majesté Impériale fondé nos espérances pour un avenir plus flatteur, il nous sera toujours facil de prouver la justice et la droiture de nos démarches, constamment décidés par le zèle dont tout bon patriote doit être animés pour le bien de sa patrie, ses lois et ses libertés, dont la garantie de la Russie a assurés la stabilité, et qui concourent naturellement à l'avantage des deux états", A.A. Czartoryski do A.P. Bestużewa-Riumina, Warszawa, 20 XII 1754 (całość autograf A.A. Czartoryskiego), AVPRI, f. 79/1, d. 1754/2, k. 35-36; tłumaczenie tegoż na rosyjski z prezentą 14/28 I 1755, ibidem, k. 39v.-40v. Na temat kontaktów zagranicznych A.A. Czartoryskiego por. K. Kuras, Wspótpracownicy i klienci Augusta A. Czartoryskiego w czasach saskich, Kraków 2010, s. 116-122.

55 „The two princes, have, each of them, wrote a letter to the great chancellor Bestoucheff, (which letters they showed me before they sent them) to express their surprise at hearing that $\mathrm{M}$. Brühl had taken the liberty to complain against them to the court of Petersburg. That, such a complaint would give them the greatest affliction if they were not thoroughly satisfied of their own innocence. That they should be glad to demonstrate it to the court of Petersburg, whenever the great chancellor pleased to call upon them. That it was now near twenty years since the empress Anna took their family into her protection. That since that time they had received many obligations from that czarina and the present. And that they had always preserved the most grateful sense of those favours. They also declared, that next to their own country, Russia was the power to whom they were most attached which they made no scruple 
oczywiste pytania, czy było to działanie świadome? Jeżeli tak, to jedynym wyjaśnieniem może być to, że Czartoryscy i Williams uznali, iż w Londynie lepiej będzie odebrane (w formie historycznej legitymizacji) przywołanie czasów, gdy Wielką Brytanię i Rosję łączyły sojusznicze relacje. Nie można jednak wykluczyć, że dyplomata okłamał swój dwór, twierdząc, że widział pisma. Można założyć, że nie otwierał otrzymanych od książąt zapieczętowanych kopert, tym bardziej iż nie wysłał odpisów listów do Whitehall. Być może więc zawartość tekstów zrelacjonował wyłącznie na podstawie samych słów Czartoryskich, ci zaś zafałszowali treść w obawie przed przeciekiem, zwłaszcza do placówki saskiej w Londynie.

Listy książąt do rosyjskiego kanclerza (wraz z uzasadnieniem podjętych przez nich działań) posłał Williams do Petersburga w przesyłce adresowanej do dyplomaty brytyjskiego w Petersburgu, Melchiora Guy Dickensa. Walijczyk wysłał je zapewne już z Drezna, dlatego dotarły nad Newę dopiero pod koniec stycznia $1755 r .{ }^{56}$ Guy Dickens nie wspomniał w oficjalnych relacjach do Londynu o swoim pośrednictwie w przekazaniu listów Czartoryskich rosyjskiemu kanclerzowi. Poinformował tylko, że otrzymywał od Williamsa informacje o sytuacji w Polsce i zamierzał rozmawiać na ten temat $z$ Bestużewem-Riuminem. Podczas rozmowy 4 lutego 1756 r. poruszono m.in. sprawy polskie, ale dyplomata nie podawał żadnych szczegółów ${ }^{57}$. Choć konieczne są tu dalsze badania, można

of owning publicly upon all occasions, and they concluded their letters with hoping for the continuation of the czarina's favour, since they were resolved, by everything in their power to endeavour to deserve it", Ch. Hanbury Williams do R. Darcy'ego Holdernessa, Warszawa, 25 XII 1754, TNA SP 88/76, k. 312v.-314.

56 „Guy Dickens świeżo odebrał pakiet od Williamsa z apologią Czartoryskich, z listami ich do Bestużewa i komunikatem o sprawie ostrogskiej, zatytułowanym Précis de tout ce qui s'est passé", J. Funcke do H. Brühla, [Petersburg], 27 I 1755 (streszczenie), W. Konopczyński, Polska $w$ dobie, s. 317, patrz też ibidem, s. 15. O tym, że listy przybyły z kurierem Guy Dickensa, mówią także adnotacje na ich rosyjskich tłumaczeniach, AVPRI, f. 79/1, d. 1754/2, k. 38, 39v. Warto w tym kontekście zwrócić uwagę na niezwiązany bezpośrednio z tytułowymi rozważaniami, ale niezwykle ważny aspekt. W źródłach nierosyjskich i za nimi w literaturze utarł się stereotyp o nadzwyczajnym wpływie Funckego na kanclerza Bestużewa (exempli gratia: „All this has been confirmed and repeated to me by M. Funcke, who is the great chancellor's friend, adviser and director. Your Lordship will hear more of him presently", Ch. Hanbury Williams do R. Darcy'ego Holdernessa, Petersburg, 23 VI/4 VII 1755, TNA SP 91/60, b.pag.). Czy jednak fakt, że Rosjanin nie przekazał Sasowi tekstów tak dla Drezna ważnych jak listy Czartoryskich, nie stanowi przesłanki, aby poddać wspomnianą konstrukcję pewnej krytyce? Tym bardziej że autor Polski $w$ dobie wojny siedmioletniej konstruował swoją narrację o polityce Rosji (w 1755 r.) przede wszystkim w oparciu o relacje Funckego znad Newy, czasami zbyt dosłownie podchodząc do ich zawartości.

${ }_{57}$ M. Guy Dickens do R. Darcy'ego Holdernessa, Petersburg, 21 I/1 II, 24 I/4 II, 28 I/8 II 1756, TNA SP 91/60, b.pag. 
zaryzykować tezę, że udało się zachować sekret co do zawartości pism z Warszawy.

Listy Czartoryskich stanowią definitywne rozstrzygnięcie przywołanej na wstępie wątpliwości Konopczyńskiego i poświadczają, że książęta popełnili „błąd ogromny, największy błąd w swojem życiu”, bowiem wystąpili o rosyjskie wsparcie, przyznając Petersburgowi zwierzchnią władzę nad Polską. Wyraźnie należy także oddać niechlubne pierwszeństwo i inicjatywę księciu Michałowi. O ile kanclerz litewski wprost sformułował podstawy gwarancji, odnosząc ją do traktatu warszawskiego, o tyle wojewoda ruski napomknął o niej tylko w samej końcówce pisma. Nie powinno to dziwić, jeżeli weźmie się pod uwagę inny aspekt, najbardziej różniący oba listy. Michał stał bowiem zdecydowanie na pozycjach konfrontacyjnych wobec dworu, obwiniając gabinet saski o akcję wymierzoną w Familię, podczas gdy August był zakorzeniony w starych schematach, upatrując główne zagrożenie w działaniach francuskich. Nie można wykluczyć także, że bracia świadomie podzielili się rolami, aby użyć szerszego wachlarza argumentów. Nie może być także wątpliwości, że to z Warszawy wypłynęła inicjatywa przywołania wydarzeń z lat 1716-1717 w formie precedensu legitymizującego rosyjską ingerencję w polski kryzys. Na marginesie relacji Grossa, w której po raz pierwszy użyty został termin „gwarancja”, rosyjski wicekanclerz Michaił Woroncow (Mihail Voroncov) poczynił dyspozycję o potrzebie zapoznania się z treścią traktatu warszawskiego ${ }^{58}$.

Opisując politykę zagraniczną Familii, Konopczyński złagodził wyraźnie własny zarzut przytoczony wyżej: „Miała zawsze kierunek antypruski, przeciwrozbiorowy, albowiem tylko przez rozbiór Polska mogła zginać, a na rozbiorze tylko Prusakom musiało już wtedy zależeć. Zacieśniać przeto związki z dworami, przeciwnymi Prusom i rozbiorowi, pod ich osłoną i w przymierzu z nimi organizować siły polskie, chociażby za cenę czasowego uznania gwarancyi, kosztem poniżeń, zdawało się polityką przezorną, bo konieczną" ${ }^{9}$. Abstrahując od innych elementów tej konstrukcji (na ogół słusznych), trzeba stwierdzić, że próba wciągnięcia Rosji w wewnętrzny konflikt w Polsce w oparciu o rzekomą gwarancję nie była krokiem „przezornym”.

Wypuszczony z butelki dżin nie wrócił posłusznie na swoje miejsce. Dokładne opisanie i przeanalizowanie sytuacji na przestrzeni następnych

58 „Упоминаемый варшавский трактат 1716 года приказать к прочтению предложить", Dyspozycja M. Woroncowa na rel. H. Grossa nr 134/1754, AVPRI, f. 79/1, d. $1754 / 5$, k. $476 \mathrm{v}$.

59 W. Konopczyński, Polska $w$ dobie, s. 141. 
lat, w czasie których odwoływano się do argumentu o rosyjskiej mediacji lub rzekomej gwarancji traktatu 1716 r., wymaga osobnego studium. Warto jednak zasygnalizować najbardziej znamienne przykłady takiego dyskursu. W marcowym reskrypcie dla Grossa z 1755 r. Petersburg przyznał sobie prawo do nieustających starań o zachowanie ustroju polskiego, przypominając mediację traktatu warszawskiego 1716 r. ${ }^{60}$ Wyraźnie słychać tu jeszcze echo bardziej umiarkowanych relacji Grossa. Jednak, gdy dyplomata rosyjski relacjonował swoją konferencję z Brühlem (31 III 1755), podczas której przedstawił zawartość reskryptu, użył już terminu "gwarancja”. Tak też raportował do Londynu Williams ${ }^{61}$. Do ustaleń z 1716 r. odwołał się również Jan Małachowski, składając Rosji jesienią $1755 \mathrm{r}$. ofertę ułożenia spraw polskich ${ }^{62}$. W instrukcji dla specjalnego rosyjskiego wysłannika do Rzeczypospolitej Iwana Weymarna (Ivan Vejmarn) z 30 maja / 10 czerwca 1756 r. Rosja już wprost uzurpowała sobie tytuł gwaranta praw polskich ${ }^{63}$.

Dojrzałą postać rzekoma gwarancja uzyskała w instrukcji dla nowego ministra w Rzeczypospolitej, Michaiła Wołkonskiego, która została sporządzona w marcu $1757 \mathrm{r}^{64}$ Tekst został podzielony na 23 punkty. W punkcie dziesiątym przywołano wspomniane wyżej propozycje kanclerza Małachowskiego, wraz z przykładem rosyjskiej mediacji (odwołano się do daty 1717 r.) jako wzorowego precedensu ${ }^{65}$. Punkt jedenasty zalecał, aby wewnętrzne polskie nieporządki, naruszające prawa i wolności,

${ }^{60}$ Elżbieta do H. Grossa, Petersburg, 24 II/7 III 1754, AVPRI, f. 79/1, d. 1755/3, k. 75v.-76v. Por. С.М. Соловьев, История России с древнейших времен, ks. 12, t. 23-24, Москва 1964, s. 243.

61 „А на седьмой пункт, в котором о Вашей гваранции трактата от 1716 года упомянуто", H. Gross do Elżbiety, Drezno, 24 III/4 IV 1755 (rel. nr 36), AVPRI, f. 79/1, d. 1755/4, k. 95v.; por. С.M. Соловьев, оp. cit., s. 245; Ch. Hanbury Williams do R. Darcy'ego Holdernessa, Drezno, 6 IV 1755, TNA SP 88/77, k. 147v., 148v.; por. P. Hanczewski, Dyplomacja brytyjska w Europie Środkowo-Wschodniej w latach 1748-1756. Misje w Berlinie, Dreźnie, Petersburgu i Wiedniu, Toruń 2001, s. 97.

${ }^{62}$ W. Konopczyński, Polska $w$ dobie, s. 143-144; 373; T. Szwaciński, „Refleksje” kanclerza koronnego Jana Małachowskiego 1755-1757, SDRE 54, 2019, 1, s. 27-57.

${ }^{63}$ Instrukcja dla I. Weymarna, Petersburg, 30 V/10 VI 1756, AVPRI, f. 79/1, d. 1756/11a, k. 19v. Patrz też: Protokół Konferencji przy Najwyższym Dworze, Petersburg, 26 III/6 IV 1756, SIRIO, t. 136: Протоколы Конференизии при Высочайшем дворе, t. 1: 14 Mapma 1756 - 13 Mapma 1757, С. Петербург 1912, s. 44.

${ }^{64}$ Instrukcja dla M.N. Wołkonskiego, Petersburg, 28 II/11 III 1757 (oryginał), AVPRI, f. 80/1, d. 556, k. 1-31 (dalej: Instrukcja). Por: T. Szwaciński, „Refleksje”, s. 51-53 (tu wcześniejsza literatura), patrz także: Б.В. Носов, Курляндское геризогтво и российско-польские отношения в 60-е годы XVIII века. К предыстории разделов Речи Посполитой, „Славяноведение”, Москва 1993, s. 58, 66.

${ }^{65}$ Instrukcja, k. 8-10v.; T. Szwaciński, „Refleksje”, s. 51-53. 
były skutecznie przezwyciężone. W sprawie szczegółów dotyczących polskiego kryzysu zalecano, aby umożliwić prymasowi swobodne wykonywanie obowiązków i aby cieszył się on protekcją króla. Podobnie upominano się o zachowanie kompetencji kanclerzy i nieprzekraczanie uprawnień przez hetmanów. Caryca Elżbieta rościła sobie także prawo do nadzorowania prawidłowego funkcjonowania sejmów, sejmików i trybunałów. Tekst instrukcji nalegał na możliwie szybkie zakończenie sporu o ordynację ostrogską, upatrując w nim główne źródło polskich napięć. Zbijając zarzuty, że Rosja ingeruje w wewnętrzne sprawy Rzeczypospolitej, Wołkonski miał deklarować, że Petersburg nie narzuca niczego, a jedynie nalega na rozwiązanie problemu przez króla i stany. Chodziło jakoby o to, aby spór ostrogski nie doprowadził do naruszenia fundamentalnych praw polskich, które caryca była zobowiązana „na mocy gwarantowanej przez jej rodziciela konstytucji 1717 r., bronić”. Najlepszy sposób na rozwiązanie sporu o ordynację upatrywano w propozycjach złożonych Rosji przez Adama Komorowskiego ${ }^{66}$.

Punkt trzynasty instrukcji nakazywał Wołkonskiemu, aby - wedle zawartości listów cyrkularnych kolportowanych przez Weymarna starał się skłaniać nieprzychylnych Rosji Polaków na stronę wschodniej sąsiadki. Za zmianę orientacji politycznej obiecywać miał ochronę i wsparcie. Kurs na Petersburg był najlepszym rozwiązaniem dla polskich interesów, ,albowiem Jej Cesarska Mość nie pragnie nic więcej, niż tylko aby każdy ze swej strony szczególnie i usilnie starał się zachować własne ich [Polaków], tutejszą gwarancją ustanowione, prawa w niewzruszonej całości". Jednak, gdyby Wołkonski dostrzegł w Polakach upór w postawach antyrosyjskich, miał podkreślać, że Elżbieta nigdy nie pogodzi się z prześladowaniem jej przyjaciół, a pozostali będą mogli zasłużyć na jej łaskę, tylko jeżeli przystaną do pierwszych. Po takiej groźbie powtórzono argument, że przyjaźń z Rosją leży w naturalnym interesie Rzeczypospolitej. Nawracanie Polaków na orientację prorosyjską miał Wołkonski prowadzić w porozumieniu z prymasem, obydwoma kanclerzami i wojewodą ruskim oraz innymi zaufanymi politykami. Przywódcy obozu przeciwnego, hetmanowi Branickiemu, w dogodnym momencie dyplomata miał oświadczyć,

że jego czyn gwałtownego ufundowania, wedle władnej woli, trybunałów, nie inaczej może być odebrany, jak tylko jako naruszenie i pogwałcenie wszystkich konstytucji i fundamentalnych praw Rzeczypospolitej, i że Jej Cesarska Mość życzy sobie widzieć, aby ten jego czyn, w jego własnym

${ }^{66}$ Instrukcja, k. 10v.-12v., zob. Aneks 1. 
interesie, został anulowany. Wzywa go jednocześnie do działań w sprawie ostrogskiej (która do tylu nieporządków doprowadziła), aby została ona sprawiedliwie i trwale zakończona, tym bardziej że Jej Cesarska Mość, jak wyżej wspomniano, na mocy gwarancji, posiada wszelkie prawo, aby nie dopuszczać do naruszenia praw i konstytucji oraz wprowadzenia jakiejkolwiek zmiany w Rzeczypospolitej.

Na zakończenie tego punktu, polecano - w celu uniknięcia nowego konfliktu na Litwie - skłaniać Michała Kazimierza Radziwiłła do porozumienia z Familią ${ }^{67}$.

W latach 1763-1764 rzekoma gwarancja stała się podstawowym argumentem legitymizującym ingerencje Petersburga w sprawy polskie ${ }^{68}$. Sprawa uzyskała finał dla Rzeczypospolitej jak najgorszy. Sejm tzw. repninowski z 1767/1768 r. formalnie uznał Rosję za gwaranta polskiego ustroju $^{69}$ - polska suwerenność została pogrzebana już nie tylko de facto ale i de jure.

\section{Aneks 1}

11e) Чтоб продолжающиеся по ныне в Польше и Литве непорядки с нарушением прав и вольностей Републики (о чем сверх того, что в сей инструкции описано, еще более и обстоятельно усмотрите вы из приложенного при сем перевода, с того представления, которое учинили через генерал-кватермейстера лейтнанта Веймарна князья Чарторижские, воевода русской да канцлер литовской) действительными и удобными средствами пересечены и всякие поводы к таким непорядкам отвращены были.

Чтоб примас королества в своем достоинстве пребывал, и в положенных на него по уставам должностях ни от кого препятствован, но властью ЕКВ-ва в том найпаче защищен и подкреплен был.

Чтоб министерския дела Републики по силе узаконеней такими особами управляемы были, которым оныя по их чинам и должности принадлежат, и чтоб особливо министерския управления у короннаго и литовского канцлеров отняты и никем иным производимы не были.

Чтоб с королевской стороны все те средства, кои с уставами сходственны, употреблены были, дабы во злоупотребленная и меру

${ }^{67}$ Instrukcja, k. 13v.-15, zob. Aneks 2.

68 Z. Zielińska, Echa dokonań, s. 320-322.

${ }^{69}$ Ibidem, s. 322. 
уже превозшедшая гетманская власть, так сокращенная была, чтоб они гетманы предписанные ими в конституциях пределы отнюдь не превосходили, но оные точно одержали и преступать более не могли.

Чтоб на сеймиках, сеймах и при установлении главных трибуналов, как в Петркове, так и в Вильне и Радоме никаких нарушении и насильств законам и всем введенным обычаям и порядкам чинено не было. В чем ЕИВ-во с своей стороны ЕКВ-во толь найпаче прдкреплять и всячески вспрмогать будет, ибо ЕИВ-во, по тем обязательствам в которых с Републикою пребывать изволит, всякое право к тому имеет.

Чтоб об острожской ординации дело (о котором вы обстоятельно сведать можете от посланника Гросса и секретаря Ржичевского) как найскорее и удобнее прекращено и успокоено было. А напрасных бы затруднени, которыя окончанию онаго токмо препатствуют, чинено и принимано не было, для того что сие дело, между иными особливой и главной повод подает и ко многому огорчению и ослаблению интересованных в оном магнатов и шляхетства, от чего найбольшаго безпокойствия в Републике, веьсма опасно.

И хотя вопреки тому иногда от некоторых представлено будет, что России, как чужестранной державе, в домашние дела Републики вмешиваться не надлежит, но напротив того можете вы предявлять, что моглобы сие толкованно быть в таком случае, ежелибы с российской стороны Републике в то время такия напомнения чинились, кагда бы оная за решение сего дела действительно принялась приговором кому маетности ординации существительно принадлежать имеют. А понеже ЕИВ-во с своей стороны в разсмотрение и решение сего дела прямо вступаться не изволит, представляя оное собственно королю и Републике, желая и советуя токмо, чтоб сие дело к общему удовольствованию короля и чинов Републики по их согласю окончалось, и чтоб по причине онаго не было нарушения государственных фундаментальных законов которые весьма обязана ЕИВ-во по силе гарантированной Ея Родителем конституции 1717го года защищать, то по сему обстоятельству не может оспорено быть России, что оная таким образом за сие дело вступаться право имеет. А каким найлутче образом и сходственно с законами Републики сие здорное дело прекращено быть может, о том для вашего наставления прилагается при сем перевод с собственной от примаса при письме к канцлеру ЕИВ-ва особливой пеьсы, в которой об оном деле важные разсуждении и способы обстоятельно показаны. И так вам найприлежнейше рекомендуется королевской польской 
двор склонять на соглашение по тем представленным от примаса резонам, чтоб тем сие неприятное дело единожды на всегда окончить.

\section{Aneks 2}

13е) А противным здешней стороне польяком имеете вы, по содержанию посланных с Веймарном циркулярных писем, внушать, что от каждого самого зависит приобрести высочайшую ЕИВ-ва милость и благоволение, и получить твердую надежность защищения и подкрепления во всяких непредвидимых приключениях, и что приобретение сих неоцененных преимуществ им ест толь удобнее и с интересами их отечества толь сходственнее, ибо ЕИВ-во не желает более, как только, чтоб каждой с своей стороны особливо и всесогласно старались сохранять свои, здешнею гарантею утвержденные уставы в ненарушаемой целости. А в прочем когда усмотрите некоторое в сих мнениях упорство поляков, имеете вы отзываться и таким образом, что как ЕИВ-во с одной стороны, ни кагда не допустит, чтоб усердствующие о благе своего отечества и по тому натуральной оному дружбе ЕИВ-ва кем бы и под каким бы то претекстом не было утесненыя или гонимы были, как с другой стороны, не откажет и тем подавать существительные записки своего благоволения и милости кои истинным соединением с первыми к тому достойными себя окажут. При сем не оставите вы им польякам толковать и весьма понятным учинить найпаче то, что они сами по собственному Републики их интересу не могут не признавать, что дружба и соединение их с Российскую империю всегда и необходимо нужны быть имеют, а они при всяком случае ни на какое другое, как токмо на высокое и сильное ЕИВ-ва защищение и вспоможение прямую надежду иметь могут. Сверх того, что еще для лутчаго преклонения поляков из противной в здешнию партию и для умножения оной говорить и толковать вам надобно и при каких случаях о том можете вы соглашаться с примасом, с коронным и литовским канцлерами и с воеводою руским князем Чарторижским, так как с надёжными для здешней стороны изнятыми в Републике персонами. А коронному гетману графу Браницкому, особливо при удобном случае, можете дать уразуметь, что его поступок в насильственном учереждении по своей воле трибуналов не инако почтен быть может, как нарушением и опровержением всех прав и фундаментальных законов Републики, и что ЕИВ-во желает 
такой его поступок, для собственной его пользы, отмененым видеть, увещевая его при том найкрепко о способствовании с его стороны по острожскому делу (которое к столь многим безпорядкам повод подало), чтоб оное по самой справедливости найскорейше прекращено было, тем найпаче, что ЕИВ-во, как выше упомянуто, по силе гарантии, всемерно право имеет, нарушения прав и законов и введение какой либо новости в Републике отнюдь не допущать, а что касается до бывших распрей между магнатами в Литве, то хотя оныя ныне уже и успокоены, но дабы по каким злостным интригам возобновлены и умножены быть не могли, то вы при таких же, как выше означено, чинимых изяснениях литовскому гетману князю Радивилу можете найсильнейше повторять, что ЕИВ-ву весьма благоудобно будет, кагда он вяще и вяще дружбою соединится с канцлером князем Чарторижским и вицеканцлером графом Сапегою, подскарбием графом Флемингом и напольным гетманом Массальским.

\section{Streszczenie}

Po zerwaniu sejmu w $1754 \mathrm{r}$. doszło do bardzo gwałtownego zaostrzenia sytuacji wewnętrznej w Rzeczypospolitej. Osią sporu była sprawa wprowadzenia w dobrach ordynacji ostrogskiej administracji państwowej, która oznaczała sekwestrację tych dóbr. Magnaci zgrupowani w tzw. partii kolbuszowskiej uznali się za skrzywdzonych i prześladowanych. Na ich czele stali bracia Czartoryscy - kanclerz litewski Michał i wojewoda ruski Aleksander. Czując swoją słabość na polskiej scenie politycznej, postanowili zwrócić się o pomoc do Rosji, tym bardziej że po ich stronie stanęli dyplomaci: rosyjski Heinrich Gross i brytyjski Charles Hanbury Williams. Aby wciągnąć dwór petersburski w sprawy polskie, Czartoryscy dowodzili, że ustrój Rzeczypospolitej (jej prawa i wolności) był gwarantowany przez Rosję na mocy postanowień traktatu warszawskiego między Augustem II a skonfederowaną szlachtą z 1716 r. Była to jednak nieprawda. Rosja była mediatorem owego traktatu, ale nigdy nie została uznana za gwaranta jego postanowień. W efekcie działań Czartoryskich Rosja zaczęła rychło uzurpować sobie status gwaranta ustroju polskiego, co znalazło wyraz $\mathrm{w}$ zapisach instrukcji dla nowego dyplomaty dworu petersburskiego w Polsce, Michaiła Wołkonskiego, w 1757 r.

\section{The Czartoryskis' Attempts to Engage Russia in Polish Internal Affairs in 1754 (the Matter of the Alleged Guarantee)}

After the breaking up of the 1754 session of the Sejm, the tension in the internal situation of the Polish-Lithuanian Commonwealth aggravated sharply. The bone of contention was the introduction of state administration in the territory of the 
Ostrogski Family Entail, which meant sequestration of the estate. The magnate members of the so-called 'Kolbuszowa Party' regarded themselves as wronged and persecuted. They were headed by Czartoryski brothers: the Lithuanian Chancellor, Michał Fryderyk, and the Palatine of Ruthenia, August Aleksander. Realizing their weakness in the Polish political scene, they decided to turn to Russia for support, especially given that they had been backed by the diplomats of Russia and Britain, Heinrich Gross and Charles Hanbury Williams respectively. To engage the court of St Petersburg in Polish affairs, the brothers Czartoryski argued that the 1716 Treaty of Warsaw between King Augustus II and the confederates made Russia a guarantor of the integrity of the Commonwealth's political system (Polish-Lithuanian rights and freedoms). However, this was not the truth. Russia acted as a mediator of the treaty, but not as a guarantor of its provisions. In consequence of the Czartoryskis' actions, Russia quickly came to usurp the status of guarantor of the Polish political system, which was reflected in the written instructions for the new Russian diplomat in Poland, Mikhail Volkonskii, in 1757.

\section{Bibliografia}

Burdowicz-Nowicki Jacek, Piotr I, August II i Rzeczpospolita 1697-1706, Arcana, Kraków 2010.

Burdowicz-Nowicki Jacek, Polityka Piotra I w związku ze sprawa toruńska 1724 r., w: W cieniu wojen i rozbiorów. Studia z dziejów Rzeczypospolitej XVIII i początków XIX wieku, red. Urszula Kosińska, Dorota Dukwicz, Adam Danilczyk, Neriton, Warszawa 2014, s. 77-103.

Butterwick Richard, Stanisław August a kultura angielska, Wydawnictwo IBL, Warszawa 2000.

Ciesielski Tomasz, Armia koronna w czasach Augusta III, DiG, Warszawa 2009.

Długosz Józef, „Transakcja Kolbuszowska 1753 r.” i jej wewnętrzne skutki polityczne, „Zeszyty Naukowe Uniwersytetu Opolskiego. Historia” 1998, 34, s. 63-70.

Dygdała Jerzy, Gra pozorów. Zabiegi dyplomacji cesarskiej o rosyjską interwencję zbrojna w Rzeczypospolitej w 1733 r., w: W cieniu wojen i rozbiorów. Studia z dziejów Rzeczypospolitej XVIII i początków XIX wieku, red. Urszula Kosińska, Dorota Dukwicz, Adam Danilczyk, Neriton, Warszawa 2014, s. 137-160.

Galas Łukasz, Szeptycki Hieronim Antoni, PSB, t. 48, Warszawa-Kraków 2012, s. 232-236. Gierowski Józef, „Opisanie” urzędów centralnych przez konfederatów tarnogrodzkich, w: O naprawę Rzeczypospolitej XVII-XVIII. Prace ofiarowane Władysławowi Czaplińskiemu w 60 rocznice urodzin, PWN, Warszawa 1965, s. 193-211.

Gierowski Józef, Traktat przyjaźni Polski z Francją w 1714 r., PWN, Warszawa 1965.

Gierowski Józef, Na szlakach Rzeczypospolitej w nowożytnej Europie, red. Andrzej K. Link-Lenczowski, Księgarnia Akademicka, Kraków 2008.

Gierowski Józef, Wokót mediacji w Traktacie Warszawskim 1716 roku, „Zeszyty Naukowe Uniwersytetu Jagiellońskiego. Prace Historyczne” 206, 1969, 26, s. 57-68.

Grześkowiak-Krwawicz Anna, Regina libertas. Wolność w polskiej myśli politycznej XVIII wieku, słowo/obraz teoria, Gdańsk 2006. 
Hanczewski Paweł, Dyplomacja brytyjska w Europie Środkowo-Wschodniej w latach 17481756. Misje w Berlinie, Dreźnie, Petersburgu i Wiedniu, Adam Marszałek, Toruń 2001.

Hanke René, Brühl und das Renversement des alliances. Die antipreußische Außenpolitik des Dresdener Hofes 1744-1756, LIT, Berlin 2006 (Historia Profana et Ecclesiastica, t. 15).

Horn David Bayne, Sir Charles Hanbury Williams and European Diplomacy (1747-1758), G.G. Harrap \& company ltd., London-Bombay-Sydney 1930.

[Konarski Stanisław], Rozmowa Ziemianina ze swoim sąsiadem. O teraźniejszych okolicznościach, Warszawa 1733.

Konopczyński Władysław, Polska $w$ dobie wojny siedmioletniej, cz. 1: 1755-1758, Gebethner i Wolff, Kraków-Warszawa 1909 (Monografie w zakresie dziejów nowożytnych).

Konopczyński Władysław, Stanisław Konarski, Wyd. Kasa im. Mianowskiego - Instytut Popierania Nauki, Warszawa 1926.

Kosińska Urszula, August II w poszukiwaniu sojusznika. Między aliansem wiedeńskim $i$ hanowerskim (1725-1730), Neriton, Warszawa 2012.

Kosińska Urszula, Liberum veto jako narzędzie niszczenia sejmów przez państwa ościenne w czasach Augusta II, „Biblioteka Epoki Nowożytnej” 4, 2016, 1, s. 127-161.

Kosińska Urszula, Sejm 1719-1720 a sprawa ratyfikacji traktatu wiedeńskiego, Semper, Warszawa 2003.

Kosińska Urszula, U źródeł zjawiska odwoływania się do potencji ościennych $w$ polskich sporach wewnętrznych - casus roku 1730, „Studia z Dziejów Rosji i Europy Środkowo-Wschodniej" 54, 2019, 1, s. 5-26.

Kościelniak Karol, Obraz mediacji rosyjskiej w listach Stanisława Ledóchowskiego adresowanych do Grzegorza Dołgorukiego z lipca i sierpnia 1716 roku znajdujacych sie w RGADA w Moskwie, w: Studia nad konfederacja tarnogrodzka i Sejmem Niemym, red. Tomasz Ciesielski, Neriton, Warszawa 2020, s. 131-142.

Kościelniak Karol, Trudnych rozmów początki. Korespondencja Stanisława Ledóchowskiego z Grigorijem Dołgorukim podczas negocjacji w Lublinie w 1716 roku, w: Sejm Niemy. Między mitem a reforma państwa, red. Michał Zwierzykowski, Wydawnictwo Sejmowe, Warszawa 2019, s. 89-112.

Kriegseisen Wojciech, Postanowienia Sejmu Niemego $w$ kwestiach wyznaniowych $i$ ich konsekwencje, czyli w sprawie genezy „sprawy dysydenckiej”, w: Sejm Niemy. Między mitem a reforma państwa, red. Michał Zwierzykowski, Wydawnictwo Sejmowe, Warszawa 2019, s. 177-188.

Kriegseisen Wojciech, Тарногродская конфедерация (1715-1717 г2.). Проявление внутреннего кризиса шляхетской Речи Посполитой или результат конфликта в отношениях России с Саксонией?, w: Россия, Польша, Германия в европейской политике. Исторический опыт взаимодействия и императивы сотрудничества, red. Борис В. Носов, Институт славяноведения, Москва 2012, s. 101-115.

Kuras Katarzyna, Wspótpracownicy i klienci Augusta A. Czartoryskiego w czasach saskich, Historia Iagellonica, Kraków 2010.

Michalski Jerzy, Lubomirski Stanisław, PSB, t. 18, Wrocław-Warszawa-Kraków 1973, s. 53-56.

Nieć Julian, Młodość ostatniego elekta. St. A. Poniatowski 1732-1764, Gebethner i Wolff, Kraków 1935. 
Šapoka Mindaugas, Konfederacja Wielkiego Księstwa Litewskiego 1715-1716 roku i jej wpływ na negocjacje przed Sejmem Niemym, w: Sejm Niemy. Między mitem a reforma państwa, red. Michał Zwierzykowski, Wydawnictwo Sejmowe, Warszawa 2019, s. 22-36.

Šapoka Mindaugas, Warfare, Loyalty, and Rebellion. The Grand Duchy of Lithuania and the Great Northern War, 1709-1717, Routledge Taylor and Francis Group, London 2018.

Sejm Niemy. Między mitem a reforma państwa, red. Michał Zwierzykowski, Wydawnictwo Sejmowe, Warszawa 2019.

Studia nad konfederacja tarnogrodzka i Sejmem Niemym, red. Tomasz Ciesielski, Neriton, Warszawa 2020.

Szwaciński Tomasz, „Refleksje” kanclerza koronnego Jana Małachowskiego 17551757, „Studia z Dziejów Rosji i Europy Środkowo-Wschowskiej” 54, 2019, 1, s. $27-57$.

Szwaciński Tomasz, Finat sejmu 1754 r.w relacjach rosyjskich i brytyjskich, „Biblioteka Epoki Nowożytnej" 4, 2016, 1, s. 163-193.

Szwaciński Tomasz, Raporty Udalryka Radziwiłła do ambasady rosyjskiej o pracach komisji dubieńskiej (styczeń-marzec 1755 r.), w: Нясвіжскі замак. Падзеi, асобы, спадчына. Матэрыялы Міжнароднай навуковай канферэнцыы, прысвечанай 435-годдзю пачатку будаўніцттва Нясвіжскага замка (Нясвіжк, 6-7 верасня 2018 г.), Нясвіж 2019, s. 182-203.

Szwaciński Tomasz, Walka „Familii” o koadiutorię wileńską: 1754-1757, w: W cieniu wojen i rozbiorów. Studia z dziejów Rzeczypospolitej XVIII i początków XIX wieku, red. Urszula Kosińska, Dorota Dukwicz, Adam Danilczyk, Neriton, Warszawa 2014, s. 197-213.

Szwaciński Tomasz, Władysław Konopczyński o szpiegu pruskim Lambercie. Pytania o orientację zagraniczna Jerzego Augusta Mniszcha, w: Władysław Konopczyński jako badacz dziejów XVIII wieku, red. Zofia Zielińska, Wojciech Kriegseisen, Wydawnictwo IH PAN, Warszawa 2014, s. 93-106.

Waliszewski Kazimierz, Potoccy i Czartoryscy. Walka stronnictw i programów politycznych przed upadkiem Rzeczypospolitej, 1734-1763, t. 1: 1734-1754, nakładem autora, Kraków 1887.

Zielińska Zofia, Echa dokonań Sejmu Niemego w czasach Augusta III i Stanisława Augusta (rekonesans), w: Sejm Niemy. Między mitem a reforma państwa, red. Michał Zwierzykowski, Wydawnictwo Sejmowe, Warszawa 2019, s. s. 286-327.

Zielińska Zofia, Rosja wobec polskich prób reform w latach 1738-1744, w: Z. Zielińska, Studia z dziejów stosunków polsko-rosyjskich w XVIII w., Semper, Warszawa 2001, s. 9-59.

Zielińska Zofia, Walka „Familii” o reformę Rzeczypospolitej 1743-1752, PWN, Warszawa 1983.

Носов Борис Владимирович, Курляндское геризогство и российско-польские отношения в 60-е годы XVIII века. К предыстории разделов Речи Посполитой, „Славяноведение", Москва 1993, s. 54-66.

Соловьев Сергей Михайлович, История России с древнейших времен, ks. 12, t. 23-24, Мысль, Москва 1964. 
Biogram: Tomasz Szwaciński, dr nauk humanistycznych; obronił rozprawę pt. „Polityka Rosji wobec Rzeczypospolitej w dobie przewrotu przymierzy (17541756)”. Zagadnieniu temu poświęcił liczne artykuły publikowane m.in. w „Kwartalniku Historycznym". Od 2012 r. zatrudniony w Bibliotece Narodowej. Główne kierunki badań: stosunki polsko-rosyjskie za Augusta III; Biblioteka Rzeczypospolitej (Załuskich); dzieje zbiorów polskich w Rosji; kontakt: t.szwacinski@wp.pl.

Author: Tomasz Szwaciński, PhD in humanities awarded for the dissertation 'The Policy of Russia towards the Commonwealth in the Period of the Reversal of Alliances (1754-56)'. He has devoted several articles to this problem, published, inter alia, in the Kwartalnik Historyczny. Since 2012, he is an employee of the National Library. His main research interests include: Polish-Russian relations under King Augustus III; the Library of the Commonwealth (of the Załuski Family); the history of Polish collections in Russia. Contact: t.szwacinski@wp.pl. 